\title{
Role of Polymeric Local Drug Delivery in Multimodal Treatment of Malignant Glioma: A Review
}

\author{
Yuan-Yun Tseng (iD) \\ Tai-Yuan Chen ${ }^{2}$ \\ Shih-Jung Liu $\mathbb{D}^{3,4}$ \\ 'Department of Neurosurgery, New \\ Taipei Municipal Tu-Cheng Hospital (Built \\ and Operated by Chang Gung Medical \\ Foundation), New Taipei City, Taiwan; \\ ${ }^{2}$ Department of Surgery, School of \\ Medicine, College of Medicine, Taipei \\ Medical University, Taipei, Taiwan; \\ ${ }^{3}$ Department of Mechanical Engineering, \\ Chang Gung University, Tao-Yuan, \\ Taiwan; ${ }^{4}$ Department of Orthopedic \\ Surgery, Chang Gung Memorial Hospital- \\ Linkuo, Tao-Yuan, Taiwan
}

\begin{abstract}
Malignant gliomas (MGs) are the most common and devastating primary brain tumor. At present, surgical interventions, radiotherapy, and chemotherapy are only marginally effective in prolonging the life expectancy of patients with MGs. Inherent heterogeneity, aggressive invasion and infiltration, intact physical barriers, and the numerous mechanisms underlying chemotherapy and radiotherapy resistance contribute to the poor prognosis for patients with MGs. Various studies have investigated methods to overcome these obstacles in MG treatment. In this review, we address difficulties in MG treatment and focus on promising polymeric local drug delivery systems. In contrast to most local delivery systems, which are directly implanted into the residual cavity after intratumoral injection or the surgical removal of a tumor, some rapidly developing and promising nanotechnological methodsincluding surface-decorated nanoparticles, magnetic nanoparticles, and focused ultrasound assist transport - are administered through (systemic) intravascular injection. We also discuss further synergistic and multimodal strategies for heightening therapeutic efficacy. Finally, we outline the challenges and therapeutic potential of these polymeric drug delivery systems.
\end{abstract}

Keywords: malignant glioma, chemoresistance, local delivery, nanofiber, nanoparticle, focused ultrasound, magnetic nanoparticles

\section{Introduction}

Malignant gliomas (MGs) come in the form of glioblastomas, anaplastic oligodendrogliomas, anaplastic astrocytomas, and anaplastic oligoastrocytomas; among these, glioblastoma multiformes (GBMs) have the highest mortality. ${ }^{1}$ MGs are highly proliferative and extensively invade the brain parenchyma, resulting in devastating tumor recurrence and poor prognosis with a median survival of approximately $12-15$ months. ${ }^{2,3}$ Although the standard treatment primarily involves surgical debulking followed by radiation therapy and possible chemotherapy, ${ }^{4-6}$ a multidisciplinary approach may be required for MGs to be managed efficiently. In the previous decades, multimodal studies and therapeutic trials have been conducted, but the advances have only extended the median survival rate of patients with MG by a few months. $5,7,8$

MGs present major therapeutic challenges because they are poorly circumscribed (Figure 1). MGs originate in glial cells ( $>90 \%$ of which are brain cells), which make neurons chemically and physically sustainable. Glioma cells aggressively invade and infiltrate healthy brain tissues through the extensive diffusion among and intermingling with surrounding brain parenchyma, making total surgical removal difficult or impossible. ${ }^{9,10}$ Furthermore, $>98 \%$ of drugs, including the most advanced
Correspondence: Shih-Jung Liu

Biomaterials Lab, Mechanical Engineering,

Chang Gung University, 259, Wen-Hwa

Ist Road, Kwei-Shan, Tao-Yuan, 33302,

Taiwan

Tel +886-3-2II86II

Fax +886-3-2118558

Email profsjliu5347@gmail.com 


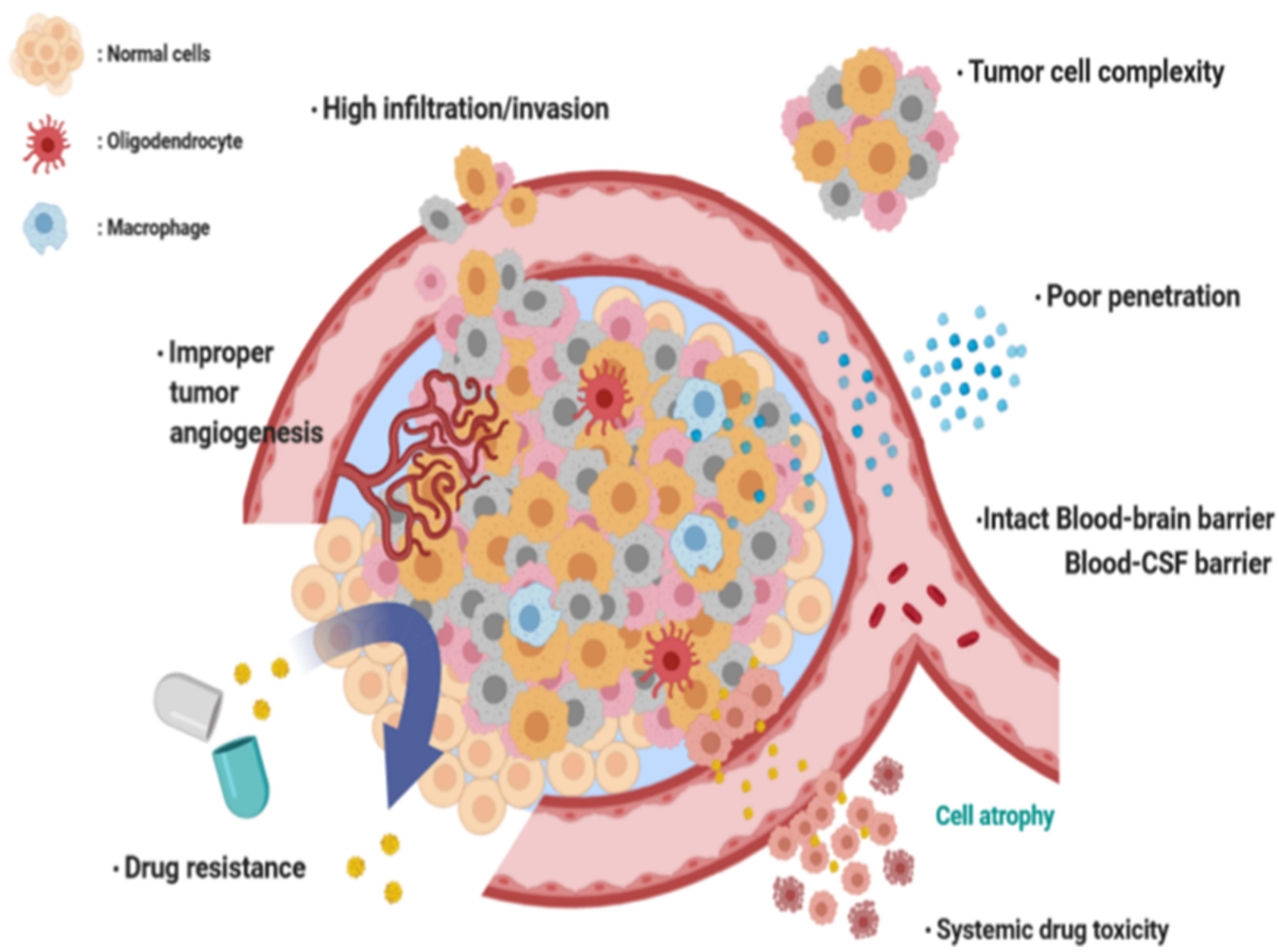

Figure I Illustrations of challenges in treating malignant glioma.

chemotherapy agents, cannot penetrate the blood-brain barrier (BBB). ${ }^{11-13}$ The BBB is a distinct coordination barrier that shields the brain from direct exposure to systemic blood. The BBB impedes the access of most therapeutic and diagnostic agents to the brain tissue even when the systemic concentration reaches a toxic level. ${ }^{12,14,15}$ Nanoscale vectors with unique characteristics have been designed to interact with cells forming the BBB at a molecular level; these vectors enable biotherapeutic molecules (such as chemotherapy agents, nucleic acids, peptides, or imaging agents) to penetrate the BBB without interrupting normal brain functions. ${ }^{15-17}$ Although the BBB may hinder the intracerebral transport of chemotherapy drugs, the major limitation of MG treatment lies in its high resistance to chemotherapy. For example, the commonly used chemotherapy drug temozolomide (TMZ) is ineffective in approximately $60-75 \%$ of patients with MG because MG tumors are unresponsive or resistant. ${ }^{18,19}$
Polifeprosan 20 with bis-chloroethylnitrosourea (BCNU, also called carmustine) is currently the only clinically used implant for the local delivery of BCNU to high-grade gliomas after tumor resection. Gliadel wafers (Guilford Pharmaceuticals, Baltimore, MD) distribute BCNU throughout the brain parenchyma over a mere 5 days. When in continuous contact with cerebrospinal fluid (CSF), the wafers biodegrade entirely within 6-8 weeks. ${ }^{20,21}$ Furthermore, a series of postimplantation complications have been reported, specifically perioperative surgical site infection, CSF leakage, meningitis, poor incisional wound healing, symptomatic malignant edema, susceptibility to seizures for at least 3 months, deep-vein thrombosis, and pulmonary embolism. ${ }^{22,23}$ In primary MG treatment, BCNU-incorporated wafers lead to improved survival without an increased incidence of adverse events, when compared with placebo wafers. However, in patients with newly diagnosed $\mathrm{GBM}^{24}$ and recurrent $\mathrm{GBM},{ }^{25}$ the median survival period increased 
by only approximately 2.3 months and 8 weeks, respectively, after they received therapy with Gliadel wafers. Furthermore, a study reported that Gliadel wafers confer no additional benefits in patients with recurrent $\mathrm{MG}^{26}$ Low local concentration, inadequate diffusion distance, a short therapeutic period, and high resistance to BCNU are the major causes of the negligible effectiveness of Gliadel wafers. ${ }^{25,27,28}$ Therefore, various innovative treatments and management modalities have been formulated in an attempt to surmount such resistance to chemotherapy. As a contribution to our understanding of the problem, this article is a review of studies on the role of polymeric vehicles for local drug delivery in the multimodal treatment of malignant glioma.

\section{Polymeric Vehicles for Local Drug Deliveries}

\section{Polymeric Vehicles}

Polymeric vehicles, especially nanoscale carriers, have gained increasing attention in recent years because of their advantages, such as high drug-loading capacity, excellent biocompatibility, and low volume requirement; these advantages, specified as follows, mean that such vehicles do not induce the mass effect when administered in the central nervous system (CNS).

1. High drug-loading capacity: Drug-loaded polymers can be fabricated as fibers, particles, micelles, or wafers (discs) that possess high porosity, open 3D porous structures, and a large surface-to-volume ratio. These properties offer numerous chemically active sites for biomolecule conjugation, ${ }^{29,30}$ which increase the drugloading capacity of polymeric carriers.

2. Low volume requirement: Due to their high drugloading capacity, manufactured polymeric carriers can have a low volume, and they do not induce the mass effect when introduced into the CNS. This is crucial in the treatment of CNS diseases. ${ }^{27,31}$

3. Excellent biocompatibility: Polymeric materials possess good biocompatibility and are thus ideal for use in drug or molecule carriers. When present in the body, these materials degrade through hydrolysis to become monomers, which, under normal physiological conditions, are byproducts of various metabolic pathways in the body. When applied to the CNS for the delivery of multiple chemotherapy agents or other bioactive agents, these highly biocompatible polymers cause no gross tissue reaction and no obvious accumulation of transudate and exudate fluids (Figure 2A and B). However, microscopic pathological examinations have indicated temporal inflammation and leucocyte accumulation from the use of such materials, with the leucocytes dissipating eventually through polymer degradation (Figure $2 \mathrm{C}$ and D). ${ }^{32-34}$

4. Biodegradability: One of the exceptional properties of polymeric materials for drug delivery to the CNS is its biodegradability. Polylactic-co-glycolic acid (PLGA) is one of the most investigated synthetic degradable polymeric materials for controlled and targeted drug delivery. It biodegrades through the hydrolysis of ester linkages in the presence of water. The duration required for PLGA degradation is determined by the ratio of the composed monomers: the greater the percentage of lactic monomers, the longer the time required for degradation relative to that for principally glycolic monomers. A special case of such regulation involves copolymers with a 50:50 monomer ratio, which degrade rapidly. This versatility in degradation has made PLGA a good candidate for use in implants as part of treatment with a tailored period and order (Figure 2C). Liu et al. ${ }^{35,36}$ exploited bistructured anticancer drug-loaded nanofibers that comprised coresheath-structured $\mathrm{O}^{6}$-BG on 50:50 PLGA nanofibers and alkylating agents (TMZ and BCNU) on 75:25 PLGA nanofibers. Hybrid-structured nanofibrous membranes (HSNMs) can sequentially deliver a high concentration of $\mathrm{O}^{6}$-BG prior to the delivery of $\mathrm{BCNU}$ and TMZ. Resistance to alkylating agents is oriented by the DNA repair protein $\mathrm{O}^{6}$-methylguanine-DNA methyltransferase (MGMT). $\mathrm{O}^{6}$-BG can necessarily inactivate MGMT through contending with $\mathrm{O}^{6}$ methylguanine, thus promoting the treatment efficacy of alkylating agents. ${ }^{36-38}$

5. Good conformity: In contrast to Gliadel wafers, most newly-developed polymeric carriers have been designed as membranes, particles, pastes, and hydrogels, and they can conform satisfactorily to the wall of the cerebral cavity after brain tumor removal and cover the brain parenchyma, thus achieving effective local drug transport. ${ }^{35,39}$

6. Easy codelivery of multi chemotherapy agents: Currently, the chemotherapy cocktail for GBM is procarbazine, lomustine (CCNU), and vincristine (PCV); in the PCV regimen, CCNU $\left(110 \mathrm{mg} / \mathrm{m}^{2}\right)$ is intravenously infused on day 1 , procarbazine $\left(60 \mathrm{mg} / \mathrm{m}^{2}\right)$ is intravenously infused daily for 14 days beginning 


\section{Nanofibrous membranes}

A Grossly appearance

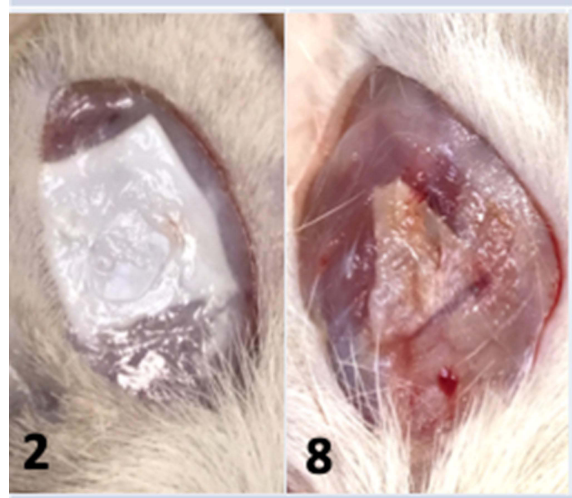

\section{Microscopic}

\section{Microparticle}

\section{B Grossly appearance}

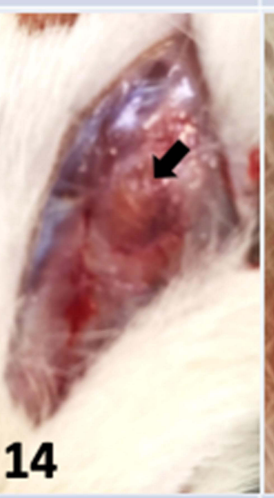

2
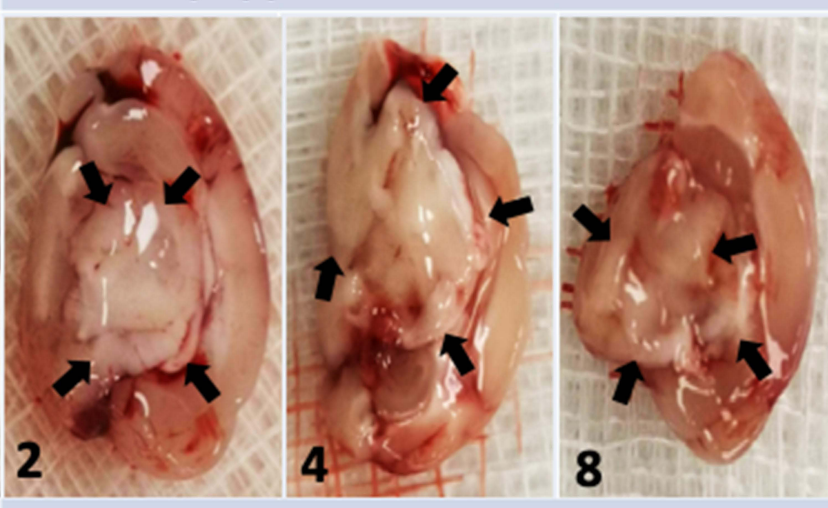

\section{Microscopic}

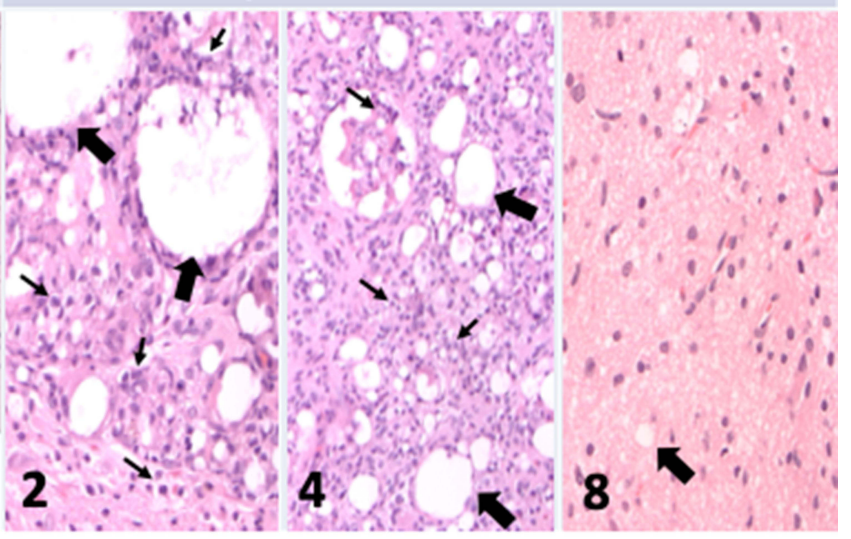

Figure 2 Gross appearances and microscopic images of postimplantation parenchyma. The number in the lower left corner of each image indicates the number of weeks following the implantation of nanofibrous membranes (NMs) or microparticles. (A) Implanted PLGA NMs degraded without causing the accumulation of transudate and exudate fluids. (B) Injected microparticles were initially dense and large (indicated by black arrows); few dense areas were observed at the end of the study. (C) Pathological examination (H\&E stain) indicated no leukocyte accumulation after implantation with NMs. The number in the lower-right corner of each image indicates cell numbers $\left(\mathrm{mm}^{2}\right)$. Progressively decreased cellularity was noted after chemotherapy agent loaded NMs implantation. (D) Injected microparticles (indicated by black arrows) degraded progressively and the presence of temporal inflammation reaction (accumulation of numerous inflamed leukocytes, indicated by small arrows). Magnification: I00x.

on day 8 , and vincristine $\left(1.4 \mathrm{mg} / \mathrm{m}^{2}\right)$ is intravenously infused on days 8 and 29 of each 6-week cycle. ${ }^{40,41}$ The PCV regimen demands an intricate course of therapy, whereas biodegradable multiagent polymeric vehicles can contemporaneously transport different chemotherapy agents ${ }^{42-45}$ or biopharmaceutic agents $^{35,46-48}$ into the CNS in one step.

\section{Local Drug Deliveries}

Although multimodal treatments are currently available, relapses of MGs are common, with $>90 \%$ of MGs recurring within $2 \mathrm{~cm}$ of the original resection cavity. ${ }^{49-51}$ Researchers have developed local and controlled drug delivery systems, such as the facilitated infusion of biotherapeutic molecules through convection-enhanced delivery, intracranially implanted catheters, or polymerbased drug delivery systems (Figure 3A). ${ }^{27,52}$ These polymer-based drug carriers exhibit promise in the treatment of brain tumors. Local delivery systems can bypass the BBB and reduce systemic toxicity, significantly increasing the therapeutic concentration at the targeted site. Chemoresistance has been primarily attributed to the increased efflux of tumoricidal agents, which results in a reduced intracellular drug reservoir. ${ }^{53,54}$ Resistance due to extraordinarily high drug efflux rates, which reduce drug concentration at the targeted site, is intrinsic or acquired if it existed before or developed after drug administration, respectively. ${ }^{53}$ Clinicians can improve therapeutic efficacy and prevent chemoresistance by increasing the anticancer drug concentration at the target tissue. 


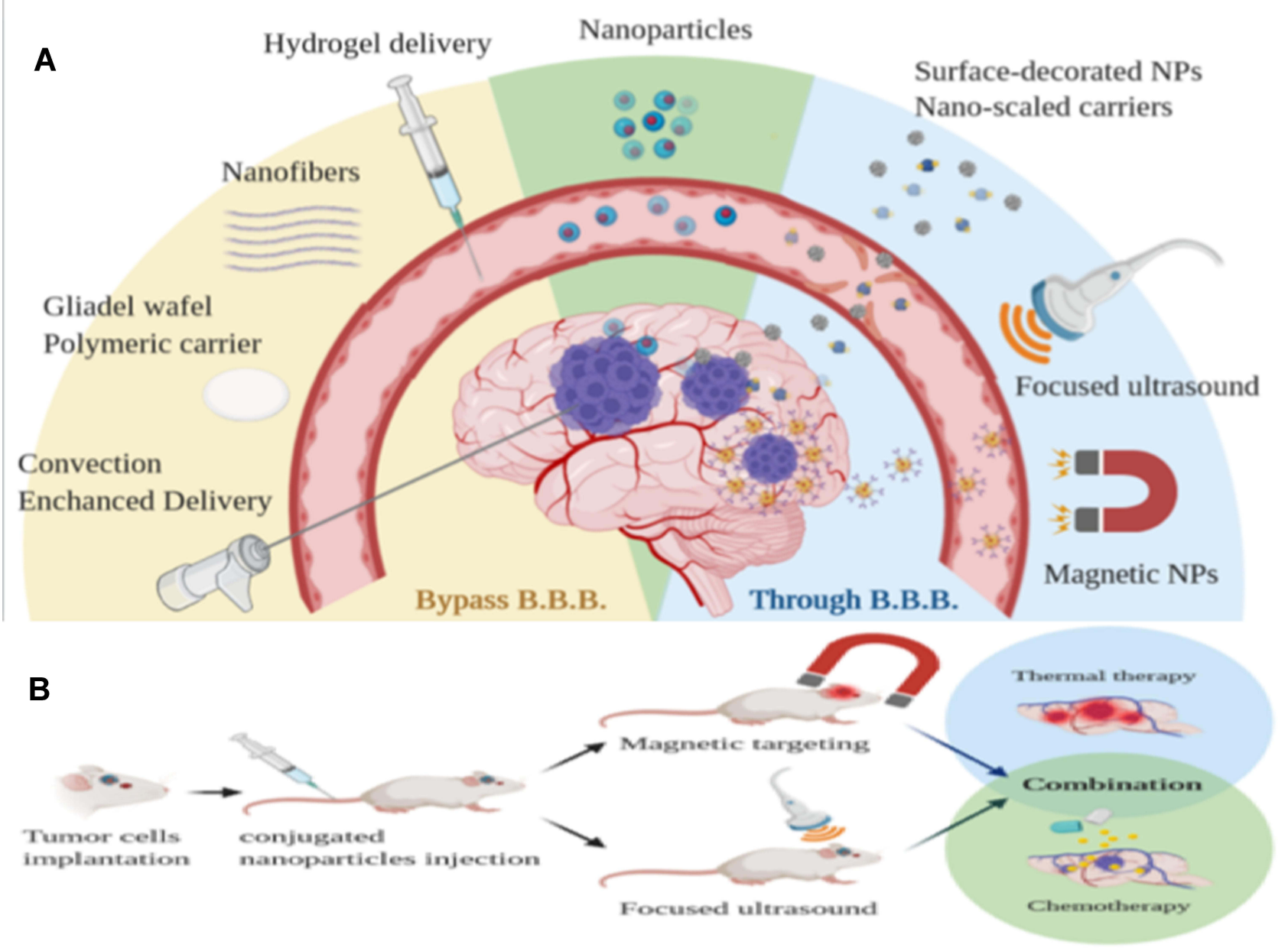

Figure 3 (A) Local delivery system that bypasses the blood-brain barrier (BBB) to reach the brain tumor. (B) NPs crossing the BBB with the aid of FUS and an external magnetic field.

Various polymers, including natural polymers, synthetic polymers, and copolymers, have been used as drug vehicles to achieve a sustained release of therapeutic molecules to targeted areas. Drug release characteristics are highly dependent on the physicochemical features of employed polymers and on their interaction with therapeutic compounds. ${ }^{55}$ To enhance therapeutic responses and prevent drug toxicity, chemotherapy may be locally administered. ${ }^{56}$ To treat malignant brain tumors, clinicians have implemented interstitial chemotherapy, in which chemotherapy agents are directly administered into tumors; it offers enhanced and extended drug concentration in the brain tissue, thus bypassing the $\mathrm{BBB}$ and minimizing systemic toxicity. Clinicians must remember the four following key points when implanting polymer-based drug delivery systems into the CNS. First, an implant with a small volume should be chosen to prevent the occurrence of the mass effect when it is introduced into the brain parenchyma or spinal cord. Second, the drug-loaded implant with the lowest toxicity should be chosen to avoid damage to functional nerve cells. Third, the implant should be implanted in a manner that induces the least inflammatory reaction, which could result in cerebral edema and poor wound healing. Fourth, care must be taken to avoid complications, such as infection and seizure, during implantation..$^{22,23,27,30}$ The theoretical benefits of polymer-based drug delivery systems have spurred the development of interstitial chemotherapy for patients with MG. ${ }^{27,57}$ Various technologies have been adopted in the development of drug-loaded polymeric implants for treating $\mathrm{MG}$, including electrospinning, ${ }^{36,42,58,59}$ electrospraying ${ }^{33}$ emulsification-solvent evaporation, ${ }^{60}$ the emulsion-evaporation method, ${ }^{61}$ and the use of selfassembly. ${ }^{32}$ Table 1 lists the polymer-based local delivery systems that have been effective in treating MG in vitro and in vivo. 
Table I Summary of Polymeric Vehicles for Local Delivery with Therapeutic Potential in MG Treatment

\begin{tabular}{|c|c|c|c|c|c|}
\hline \multicolumn{6}{|l|}{ Single Agent } \\
\hline $\begin{array}{l}\text { Therapeutical } \\
\text { Agent }\end{array}$ & Type of Polymer & $\begin{array}{l}\text { Structure of } \\
\text { Polymeric } \\
\text { Vehicle }\end{array}$ & $\begin{array}{l}\text { In vivo/in vitro } \\
\text { Model }\end{array}$ & Treatment Outcome & Ref. \\
\hline SN-38 & PLGA & MP & $\begin{array}{l}\text { Orthotopic glioma } \\
\text { rats (F98) }\end{array}$ & Significant therapeutic efficacy & [33] \\
\hline SN-38 & NK-0I 2 & Micelle & $\begin{array}{l}\text { Orthotopic GS rats } \\
\text { and GBM mice (9L, } \\
\text { U87) }\end{array}$ & Excellent efficacy & [68] \\
\hline $\mathrm{SN}-38$ & PLEC & Depot & $\begin{array}{l}\text { Orthotopic GBM mice } \\
\text { (U87) }\end{array}$ & $\begin{array}{l}\text { Better antitumor efficacy and reduced } \\
\text { toxicity }\end{array}$ & [69] \\
\hline $\mathrm{SN}-38$ & PCL/GT & Nanofiber & $\begin{array}{l}\text { In vitro U25I/ U87 } \\
\text { cell }\end{array}$ & Good anti-tumor function in vitro & {$[70]$} \\
\hline $\mathrm{BCNU}$ & Poly-CPP-SA & Disc & $\begin{array}{l}\text { Orthotopic GS rats } \\
(9 L)\end{array}$ & $\begin{array}{l}\text { Effective antitumor efficacy and } \\
\text { prolong survival rate }\end{array}$ & [64] \\
\hline $\mathrm{BCNU}$ & PEG-PLA & Ultrafine fiber & $\begin{array}{l}\text { In vitro, C6 glioma } \\
\text { cell, }\end{array}$ & Not affect the growth of $\mathrm{C} 6$ glioma cell & {$[58]$} \\
\hline $\mathrm{BCNU}$ & PLGA & Wafer & 9L GS, subcutaneous & Delayed tumor growth & {$[62]$} \\
\hline $\mathrm{BCNU}$ & PLGA & Wafer & In vitro, $\mathrm{XF}-498$ cell & Increase antitumor activity & [63] \\
\hline $\mathrm{BCNU}$ & PLGA & Nanofiber & In vivo, concentration & $\begin{array}{l}\text { Sustained release high concentration }> \\
8 \text { week }\end{array}$ & [39] \\
\hline $\mathrm{BCNU}$ & $\begin{array}{l}\text { Shell: } \mathrm{panH} \\
\text { Core: } \mathrm{Fe}_{3} \mathrm{O}\end{array}$ & $\begin{array}{l}\text { Core-shell } \\
\text { magnetic NP }\end{array}$ & In vivo, concentration & $\begin{array}{l}\text { Increase the concentration and } \\
\text { retention }\end{array}$ & {$[119,137]$} \\
\hline Rapamycin & $\begin{array}{l}\text { Caprolactone-glycolide } \\
(35: 65)\end{array}$ & Beads & $\begin{array}{l}\text { Orthotopic GS rats } \\
\text { (9L) }\end{array}$ & Significant increase in survival & [65] \\
\hline Doxorubicin & Polysorbate & $\begin{array}{l}\text { Polysorbate- } \\
\text { coating NP }\end{array}$ & $\begin{array}{l}\text { Orthotopic glioma } \\
\text { rats }(101 / 8)\end{array}$ & Considerable antitumor effect & [138] \\
\hline Doxorubicin & PLGA & NP & $\begin{array}{l}\text { Orthotopic glioma } \\
\text { rats }(101 / 8)\end{array}$ & Considerable anti-tumor effect & [139] \\
\hline 5-FU & PLGA & Wafer & $\begin{array}{l}\text { Orthotopic glioma } \\
\text { rats }(\mathrm{C} 6)\end{array}$ & $\begin{array}{l}\text { Drug diffusion is limited to the } \\
\text { implantation site. }\end{array}$ & [140] \\
\hline 5-FU & PLGA & Microspheres & $\begin{array}{l}\text { Orthotopic glioma } \\
\text { rats }(\mathrm{C} 6)\end{array}$ & Decrease mortality & {$[14 \mid]$} \\
\hline Bucladesine & PLGA & Pellets & Clinical GBM patient & Delay of recurrence & {$[142]$} \\
\hline $\begin{array}{l}\text { n-butyliden- } \\
\text { ephthalide }\end{array}$ & Polyanhydride & Wafer & In Vitro GBM cell line & $\begin{array}{l}\text { Increased the survival rate and } \\
\text { inhibited tumor invasion. }\end{array}$ & {$[28]$} \\
\hline$T M Z$ & MPC & $\begin{array}{l}\text { Nanostructures } \\
\text { from the block }\end{array}$ & $\begin{array}{l}\text { Orthotopic GBM mice } \\
\text { (U87 and T98) }\end{array}$ & $\begin{array}{l}\text { 2- to 19-retention times longer than } \\
\text { that of free TMZ. }\end{array}$ & {$[143]$} \\
\hline Idarubicin & PLGA, PGACL & Wafer & $\begin{array}{l}\text { In vitro (U87MG cell } \\
\text { line). }\end{array}$ & High inhibition of proliferation & [144] \\
\hline
\end{tabular}


Table I (Continued).

\begin{tabular}{|c|c|c|c|c|c|c|}
\hline Paclitaxel & PLGA, PEG & NP & $\begin{array}{l}\text { Orthotopic GS rats } \\
\text { (9L) }\end{array}$ & \multicolumn{2}{|c|}{$\begin{array}{l}\text { Delayed tumor growth and enhance } \\
\text { drug distribution }\end{array}$} & [145] \\
\hline Camptothecin & EVAc & Particles & $\begin{array}{l}\text { Orthotopic GS rats } \\
\text { (9L) }\end{array}$ & \multicolumn{2}{|c|}{ Significantly extended survival } & [66] \\
\hline Doxorubicine & PLA, BEP & Patch & $\begin{array}{l}\text { Orthotopic U87-MG } \\
\text { canine }\end{array}$ & \multicolumn{2}{|c|}{$\begin{array}{l}\text { Suppressed tumor volume and } \\
\text { enhanced survival rate }\end{array}$} & {$[146]$} \\
\hline \multicolumn{7}{|c|}{ Multiple Agents } \\
\hline \multicolumn{7}{|c|}{ Concurrent Different Chemotherapy Agents } \\
\hline $\begin{array}{l}\text { Therapeutical } \\
\text { Agent }\end{array}$ & Type of Polymer & $\begin{array}{l}\text { Structure of } \\
\text { Polymeric } \\
\text { Vehicle }\end{array}$ & $\begin{array}{l}\text { In vivo/in vitro } \\
\text { Model }\end{array}$ & \multicolumn{2}{|c|}{ Treatment Outcome } & Ref. \\
\hline $\begin{array}{l}\text { BCNU, } \\
\text { Cisplatin, } \\
\text { Irinotecan }\end{array}$ & PLGA & Nanofiber & $\begin{array}{l}\text { Orthotopic glioma } \\
\text { rats }(\mathrm{C} 6)\end{array}$ & \multicolumn{2}{|c|}{$\begin{array}{l}\text { Prolong survival and reduced the } \\
\text { malignancy }\end{array}$} & {$[42,43]$} \\
\hline $\begin{array}{l}\text { Emozolomide, } \\
\text { Etoposide }\end{array}$ & PLGA/PEG & MP/ paste & $\begin{array}{l}\text { Orthotopic GS rats } \\
\text { (9L) }\end{array}$ & \multicolumn{2}{|c|}{ Significant overall survival benefit } & [44] \\
\hline \multicolumn{7}{|c|}{ Combined Other Biotherapeutic Agent } \\
\hline $\begin{array}{l}\text { Therapeutic } \\
\text { Agent }\end{array}$ & Biotherapeutic Agent & $\begin{array}{l}\text { Type of } \\
\text { Polymer }\end{array}$ & $\begin{array}{l}\text { Structure of } \\
\text { Polymeric Vehicle }\end{array}$ & $\begin{array}{l}\text { In vivo/in vitro } \\
\text { Model }\end{array}$ & $\begin{array}{l}\text { Treatment } \\
\text { Outcome }\end{array}$ & Ref. \\
\hline $\begin{array}{l}\text { BCNU, } \\
\text { Cisplatin, } \\
\text { Irinotecan }\end{array}$ & $\begin{array}{l}\text { Antiangiogenic } \\
\text { (Combretastatin) }\end{array}$ & PLGA & Bi-layered NM & $\begin{array}{l}\text { Orthotopic GS, } \\
\text { glioma rats (9L, } \\
\text { F98) }\end{array}$ & $\begin{array}{l}\text { Prolong survival } \\
\text { and reduced } \\
\text { tumor progression } \\
\text { and malignancy }\end{array}$ & {$[46,86]$} \\
\hline BCNU, TMZ & $\mathrm{O}^{6}-\mathrm{BG}$ & PLGA & $\begin{array}{l}\text { Hybride -structured } \\
\text { NM }\end{array}$ & $\begin{array}{l}\text { Orthotopic } \\
\text { glioma rats (9L, } \\
\text { F98) }\end{array}$ & $\begin{array}{l}\text { Prolong survival } \\
\text { and reduced } \\
\text { tumor progress } \\
\text { and malignancy }\end{array}$ & {$[35,36]$} \\
\hline Irinotecan & Metformin & PLGA & NP & $\begin{array}{l}\text { In vitro GBM cell } \\
(\mathrm{U}-87) \text { and } \\
\text { Orthotopic } \\
\text { GBM mice (U87) }\end{array}$ & $\begin{array}{l}\text { Significantly } \\
\text { reduced the } \\
\text { volume of } \\
\text { extracted cancer }\end{array}$ & {$[90]$} \\
\hline None & $\begin{array}{l}\text { T-lymphocyte-associated } \\
\text { antigen } 4 \text { (a-CTLA-4) and } \\
\text { programmed cell death-I } \\
\text { (a-PD-I) }\end{array}$ & $\begin{array}{l}\operatorname{Poly}(\beta \text {-L-malic } \\
\text { acid })\end{array}$ & NP & $\begin{array}{l}\text { Orthotopic } \\
\text { GBM mice } \\
(\text { GL26I) }\end{array}$ & $\begin{array}{l}\text { Effective GBM } \\
\text { treatment via } \\
\text { activating immune } \\
\text { response. }\end{array}$ & [47] \\
\hline None & $\begin{array}{l}\text { Several anti-GBM genes } \\
\text { (Robol, YAPI, NKCCI, } \\
\text { EGFR, and survivin) }\end{array}$ & PBAE & NP & $\begin{array}{l}\text { Orthotopic mice } \\
\text { model of human } \\
\text { GBM cell }\end{array}$ & $\begin{array}{l}\text { Leads to high } \\
\text { GBM cell death, } \\
\text { reduces GBM } \\
\text { migration }\end{array}$ & [48] \\
\hline None & $\begin{array}{l}\text { siRNA, linear DNA, and } \\
\text { circular DNAs }\end{array}$ & PBAE & NP & $\begin{array}{l}\text { In vitro, GBM } \\
319 \text { cells }\end{array}$ & $\begin{array}{l}\text { Increase delivery } \\
\text { of both DNA and } \\
\text { siRNA }\end{array}$ & [147] \\
\hline
\end{tabular}


Table I (Continued).

\begin{tabular}{|c|c|c|c|c|c|c|}
\hline None & Binimetinib & $\begin{array}{l}\text { Poly(butadiene- } \\
\text { b-ethylene } \\
\text { oxide) }\end{array}$ & Polymersomes & $\begin{array}{l}\text { In vitro BBB } \\
\text { model }\end{array}$ & $\begin{array}{l}\text { Cross the in vitro } \\
\text { BBB model }\end{array}$ & [148] \\
\hline None & siRNA & Chitosan & NP & $\begin{array}{l}\text { Orthotopic mice } \\
\text { model (GL26I) }\end{array}$ & $\begin{array}{l}\text { Targeting Gal-I } \\
\text { gene, effective } \\
\text { treatment of GBM }\end{array}$ & {$[149,150]$} \\
\hline None & Curcumin & $\begin{array}{l}\text { PLGA } \\
\text { Chitosan }\end{array}$ & NP & $\begin{array}{l}\text { RG2 rat glioma } \\
\text { model }\end{array}$ & $\begin{array}{l}\text { Tumor size } \\
\text { decreased } \\
\text { significantly }\end{array}$ & [91] \\
\hline Paclitaxel & Curcumin & PLGA & MNP & $\begin{array}{l}\text { Orthotopic mice } \\
\text { model (U87) }\end{array}$ & $\begin{array}{l}\text { Prolong survival } \\
\text { and reduced } \\
\text { tumor size }\end{array}$ & {$[121]$} \\
\hline
\end{tabular}

Abbreviations: GBM, glioblastoma multiforme; GS, gliosarcoma; PLGA, poly(L-lactide-co-glycolide); PGACL, poly(glycolide-co- $\varepsilon$-caprolactone); PBAE, poly(beta-amino ester); PEG-PLA, poly(ethylene glycol)-poly(L-lactic acid); MPC, 2-methacryloyloxyethyl phosphorylcholine; EVAc, ethylene-vinyl acetate co-polymer; MP, microparticle; NM, nanofibrous membrane; NP, nanoparticle; BEP, biodegradable electronic patch.

\section{Monotherapies}

BCNU is considered to be the most effective systemic chemotherapy for MG and has been widely used for local chemotherapy. Studies have incorporated BCNU into both PLGA ${ }^{39,62,63}$ and copolymers, such as polyCPP-SA $^{64}$ and poly(ethylene glycol)-poly(L-lactic acid)

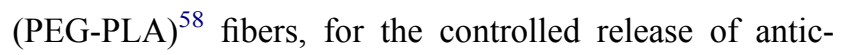
ancer agents. In a previous study, the antitumor activity of BCNU-loaded fibers was consistently high throughout the experimental process whereas that of pristine $\mathrm{BCNU}$ diminished within $48 \mathrm{~h}$. These results suggest that BCNU/PEG-PLLA fibers provide the sustained release of BCNU and are suitable for chemotherapy after the surgical removal of brain tumors. ${ }^{58}$

Some chemotherapy agents that cannot effectively pass through the BBB have been incorporated into polymers for interstitial MG chemotherapy. These chemotherapy agents, such as doxorubicin, rapamycin, and bucladesine, have been used to effectively treat cancers other than MG. Rapamycin was loaded into biodegradable caprolactone-glycolide (35:65) polymer beads at $0.3 \%, 3 \%$, and $30 \%$ loading doses and implanted intracranially. Dose-escalating rapamycin bead treatment had a significant increase in survival relative to orthotopic glioma controls in rats. ${ }^{65}$ Camptothecin was loaded into a controlled-release polymer (ethylene-vinyl acetate copolymer), and its efficacy was tested in 9L gliosarcoma orthotopic rats. Survival was significantly extended only when camptothecin was delivered locally through a polymer; camptothecin that was injected directly into the tumor through systemic administration did not extend survival. ${ }^{66}$
Irinotecan, a topoisomerase I inhibitor, is effective in treating many malignancies, including fluorouracilresistant colorectal cancer. The potent chemotherapy agent 7-ethyl-10-hydroxycamptothecin ( $\mathrm{SN}-38)$ is the active metabolite of irinotecan and is approximately 100 1000-fold more potent than irinotecan. ${ }^{33,67}$ However, inherently poor aqueous solubility and inherent instability at $\mathrm{pH}>6$ hamper the direct utility of SN-38; consequently, several pro-drug, polymer-conjugated micelles, fibers, particles, and implants were investigated to improve SN-38's biopharmaceutic properties. ${ }^{67} \mathrm{SN}-38$ has been loaded into various polymers, including PLGA, ${ }^{33} \mathrm{NK}-012,{ }^{68}$ PLEC, ${ }^{69}$ and $\mathrm{PCL} / \mathrm{GT}^{70}{ }^{70}$ for local delivery. These drug-loaded polymers exhibited superior antitumor properties in vitro ${ }^{70}$ and in an orthotopic animal model. ${ }^{33,68,69}$ Furthermore, SN-38 was embedded into 50:50 biodegradable PLGA microparticles through the electrospraying technique and stereotactically injected into the tumors of F98 orthotopic glioma rats. The study outcomes demonstrated the significant treatment benefits of SN-38-incorporated PLGA microparticles with respect to extended survival, decelerated tumor growth, and attenuated malignancy. ${ }^{33}$

\section{Multiagent Treatments}

Due to the heterogeneity of cancer, treatment with a single agent is usually insufficient for suppressing cancer growth and metastasis. In a previous study, single-agent chemotherapy was only marginally effective in treating rare human malignancies. ${ }^{71}$ To reduce chemoresistance, studies have investigated several chemotherapy 
agents with different tumor-inhibiting mechanisms. ${ }^{8,71,72}$ Special groups of biopharmaceutical agents that comprise, for example, chemotherapy agents, antiangiogenic agents, cytotoxin, and peptides, have been concurrently administered for immune and gene therapy. Studies have demonstrated that the concurrent delivery of various biotherapeutic molecules with different physiochemical properties to tumor sites reduces the required dosage of chemotherapy agents and achieves synergistic therapeutic effects in treating cancers, ${ }^{73,74}$ thus minimizing doserelated side effects and preventing or delaying drug resistance. $^{75,76}$ Further studies and clinical trials in patients with glioblastoma are required to determine the optimal combination therapies that overcome drug resistance. $^{76}$

The regimen of administering a chemotherapy agent at a relatively low, minimally toxic dosage for prolonged periods with no extended drug-free interval is called periodic chemotherapy. ${ }^{77}$ Using a human melanoma xenograft model, Wedge et al demonstrated that the prolonged administration of $\mathrm{O}^{6}$-benzylguanine $\left(\mathrm{O}^{6}-\mathrm{BG}\right)$ in combination with TMZ can increase the therapeutic index of TMZ. ${ }^{35,78,79}$ However, high drug toxicities and the associated side effects are caused by strategies such as combining different biopharmaceutical agents, increasing the targeted area concentration, and prolonging the treatment.

Because cancer is complex, combination chemotherapy is required to treat brain tumors. Formulated to treat MGs (particularly GBM, gliomas, and astrocytomas), the PCV regimen necessitates a complex treatment procedure, comes with a high drug toxicity, and yields only marginal therapeutic benefits. ${ }^{41,42}$ To address this problem, Tseng et al adopted biodegradable nanofibrous membranes (NMs) to concurrently distribute three chemotherapy agents with different therapeutic mechanisms in one procedure to treat surgically resected gliomas; ${ }^{42}$ this method was more effective than the PCV regimen for treating MG. Smith et al. ${ }^{44}$ used a blend of PLGA and PEG paste and combined TMZ and etoposide to treat high-grade glioma following surgical removal. The experimental results suggested a significant overall improvement in survival among postoperative 9L gliosarcoma-bearing rats treated with intracavity-delivered PLGA/PEG/TMZ/etoposide and adjuvant radiotherapy. The PLGA/PEG paste may also serve as an outstanding platform for the combinatorial delivery of molecular-targeted compounds.

\section{Combined Treatments with} Nonchemotherapy Bioactive Agents Antiangiogenetic Agent

MG characteristically exhibits vigorous but improper neovascularization (angiogenesis); it has thus received extensive attention as part of the development of antiangiogenic therapeutic strategies for MG. The suppression of angiogenesis - that is, the gemmation of new capillaries from pre-existing vasculature, which is crucial in mature gliomas larger than a few cubic millimeters - is a highly promising treatment strategy that interferes with the growth of gliomas. ${ }^{46,80-82}$ Furthermore, to curb drug resistance, clinicians may need to adopt antiangiogenic strategies that induce apoptosis or the death of neovasculates. ${ }^{83,84}$ Tseng et al. ${ }^{85,86}$ concurrently impregnated three chemotherapy agents (BCNU, irinotecan, and cisplatin) into 50:50 PLGA nanofibers and an antiangiogenic agent (combretastatin) into 75:25 PLGA nanofibers. Compared with C6 glioma-bearing rats treated without antiangiogenic agents, C6 orthotopic glioma rats treated with antiangiogenic agent-incorporated NMs exhibited retarded tumor growth and attenuated malignancy.

\section{Immunotherapy}

Immunotherapy for brain gliomas is largely unsuccessful because inhibitor antibodies cannot cross the BBB. Galstyan et al. ${ }^{47}$ used poly( $\beta$-L-malic acid), a natural polymer, to deliver covalently conjugated cytotoxic T-lymphocyte-associated antigen- 4 and programmed cell death-1 antibodies to brain cancer cells, which led to local immune system activation and extended survival among intracranial GL261 GBM orthotopic mice. Moreover, their study demonstrated that the trans-BBB delivery of tumortargeted polymer-conjugated checkpoint inhibitors is a valuable method for MG therapy that acts through the activation of the systemic and local privileged brain tumor immune response. ${ }^{47}$

\section{Gene Therapy}

Gene therapy implicates the delivery of genes that treat cancer cells. Kozielski et al. ${ }^{48}$ designed poly(beta-amino ester), a synthetic, biodegradable polymer, that simultaneously incorporates and transports hundreds of siRNA molecules to several anti-GBM genes (Robo1, YAP1, NKCC1, EGFR, and survivin). Their results demonstrated high GBM cell apoptosis, reduced GBM migration in vitro, and decreased tumor burden over time after 
intratumoral injection. ${ }^{48}$ The resistance of brain tumor cells to alkylating agents is managed by the DNA repair protein MGMT. $\mathrm{O}^{6}-\mathrm{BG}$ irrevocably deactivates MGMT through contestation with $\mathrm{O}^{6}$-methylguanine, thus elevating the therapeutic sensitivity and activity of alkylating agents. ${ }^{35,37}$ Liu et al. ${ }^{35,36}$ developed HSNMs that enable the transporting of $\mathrm{O}^{6}-\mathrm{BG}$ prior two alkylators (BCNU and TMZ) and provide the sustained release of drugs for $>8$ weeks. The HSNMs were inculcated into the tumor cavity of F98 glioma-bearing rats through surgery. The HSNMtreated group exhibited a decelerated glioma growth rate and extended mean survival time compared with the rats treated with an intraperitoneal injection of $\mathrm{O}^{6}-\mathrm{BG}$ in combination with surgical transplantation of carmustine wafer and oral TMZ.

\section{Other Nonchemotherapy Agents}

Metformin, 1,1-dimethylbiguanide hydrochloride is used as first-line medication for type II diabetes mellitus. A recent investigation reported that the drug possesses anticancer properties against many types of tumors, including those associated with colon, breast, prostate, and pancreatic cancers; leukemia; melanoma; lung and endometrial carcinoma; and gliomas. ${ }^{55}$ Metformin treatment has been demonstrated to reduce the proliferation rate of tumor-initiating cell-enriched cultures, which were isolated from four human GBMs. ${ }^{55,87}$ The administration of a high dose of metformin combined with TMZ inhibited fatty acid synthase expression in an orthotopic model. The inhibition of fatty acid synthase might be a potential therapeutic target of GBM. ${ }^{88}$ The radiosensitizing effects of metformin on glioblastoma cells treated with irradiation and TMZ in vitro was consistent in terms of G2/M arrest and changes in pAMPK levels. ${ }^{89}$ Nevertheless, the systemic administration of high-dose metformin results in severe hypoglycemia. The local delivery of metformin using a polymer is an alternative treatment strategy. Taghizadehghalehjoughi et al developed irinotecan- and metformin-loaded PLGA nanoparticles (NPs) and tested them on U-87 MG glioblastoma cells and on an animal model to evaluate their efficacy in GBM treatment. Their results demonstrated that metformin- and irinotecanloaded PLGA NPs significantly decrease the volume of extracted cancer. ${ }^{90}$ Curcumin (CCM) has shown promise for the treatment of GBM in experimental models. CCMloaded chitosan-PLGA NPs modified with sialic acid were reported to efficiently traverse the BBB and subsequently inhibit the proliferation of glioblastoma cells. ${ }^{91}$

\section{Thermal Therapy}

The prognosis of glioma is still poor despite advances in radiotherapy techniques. ${ }^{92}$ Glioma resistance to chemoradiation therapy may partly result from the hypoxic area within the tumor. ${ }^{92,93}$ Hypoxic cells have great potential because they can infiltrate into the brain tissue and locally extend the tumor. Hyperthermia therapy (HT) is a recognized treatment modality that can sensitize tumors to the effects of radiotherapy (RT) and chemotherapy by heating tumor cells to 40 to $45^{\circ} \mathrm{C} .{ }^{93-97}$ Specifically, intralesional temperature is monitored throughout HT using MRI thermometry, which offers visual indications of temperature over a definite period; the high temperature induces cell death, usually at $43^{\circ} \mathrm{C}$ for 10 min. $^{98,99}$ Magnetic resonance imaging-guided laser interstitial thermal therapy was demonstrated to be safe and effective in selected patients with GBMs and may add an average of 2 months to the patient's life expectancy relative to the current standard of care. ${ }^{100} \mathrm{Li}$ et al. ${ }^{101}$ reported a nanotherapeutic vehicle established on bis-diketopyrrolopyrrole conjugated polymer (PBDPP) NPs with remarkable near-infrared (NIR) absorption at $808 \mathrm{~nm}$ and high photothermal energy conversion efficiency up to $60 \%$. Their results revealed that the precise glioblastoma-specific capability and killing ability of glioblastoma cells can be effectively realized in vitro by dealing with only PBDPP NPs to incur cell apoptosis or by interacting with PBDPP NPs under NIR laser irradiation to trigger cell necrosis. ${ }^{101}$ Antigliomal efficacy can be enhanced by coupling HT with chemotherapy ${ }^{102}$ and radiotherapy. ${ }^{103}$ Although the literature is limited by small sample sizes and the dominance of retrospective studies, HT is considered a safe and effective treatment for brain lesions when applied in the correct patient population..$^{95,104,105}$

\section{Strategies for Enhancing Efficacy at the Target Site}

Nanoscale drug delivery systems have demonstrated outstanding potential in delivering drugs through the BBB with minimal side effects. Nanoparticles and nanofibers, especially those measuring approximately $100 \mathrm{~nm}$, are likely to be advantageous because they are absorbed by cells at rates 15-250 times faster than those of microparticles and microfibers. ${ }^{106-109}$ Furthermore, the nanocarrier surface can be functionalized with molecules, such as therapeutic agents, peptides, antibodies, and RNA aptamers, and macromolecules can be bound to receptors 
appearing at the endothelial cell surface of the BBB. This ensures that the nanocarriers can penetrate the $\mathrm{BBB}$ and subsequently deliver biomacromolecules to the brain for the treatment or imaging of neurological disorders. During the imaging and treatment of brain tumors, nanocarriers can serve theranostic purposes as both an MRI-based contrast agent and a radiosensitizer. ${ }^{110-112}$

In our previous study, we developed biodegradable PLGA NMs to incorporate BCNU; the in vivo drug concentration results revealed that BCNU-loaded NMs consistently released high levels of BCNU into the cerebral cavity of rats over a 6-week period (Figure 4A). ${ }^{39}$ Moreover, we concurrently embedded three chemotherapy agents (namely BCNU, irinotecan, and cisplatin) with different mechanisms into PLGA NMs, and the results revealed that anticancer drug-eluting PLGA nanofibers can promote the sustained and concurrent transport of various chemotherapy agents into the brain parenchyma, thus strengthening the efficacy of MG therapy and avoiding the influence of toxicity from a systemic regimen of chemotherapy agents. ${ }^{42,43}$ Furthermore, we concurrently embedded three chemotherapy drugs (namely BCNU, irinotecan, and cisplatin) into 50:50 PLGA nanofibers and added an antiangiogenic agent (combretastatin) to 75:25 PLGA nanofibers to fabricate double-layer NMs. The chemotherapy agents were swiftly eluted from the 50:50 PLGA nanofibers after surgical implantation, and combretastatin was eluted from the 75:25 PLGA nanofibers approximately 2 weeks later. All drug levels were higher in the brain tissues than in the blood for $>8$ weeks (Figure 4B). ${ }^{86}$ The double-layered NM was surgically implanted into C6 glioma-bearing rats. The efficacy of the double-layer NMs was empirically indicated by, for example, attenuated malignancy, retarded tumor growth, and prolonged survival in glioma-bearing rats (Figure 4D). ${ }^{46}$ Furthermore, we used 50:50 PLGA to embed $\mathrm{O}^{6}$-BG and developed nanofibers with a coresheath and used 75:25 PLGA to load BCNU and TMZ; we also exploited single-strain nanofibers. The two types of nanofibers were merged to form HSNMs. The biodegradable HSNMs sequentially and sustainably transported high levels of $\mathrm{O}^{6}-\mathrm{BG}, \mathrm{BCNU}$, and TMZ over 14 weeks (Figure 4C). HSNM treatment yielded therapeutic advantages with regard to retarded and restricted tumor growth, prolonged survival time, and attenuated malignancy in rats with orthotopic glioma (Figure 4D). ${ }^{35,36}$ Biodegradable
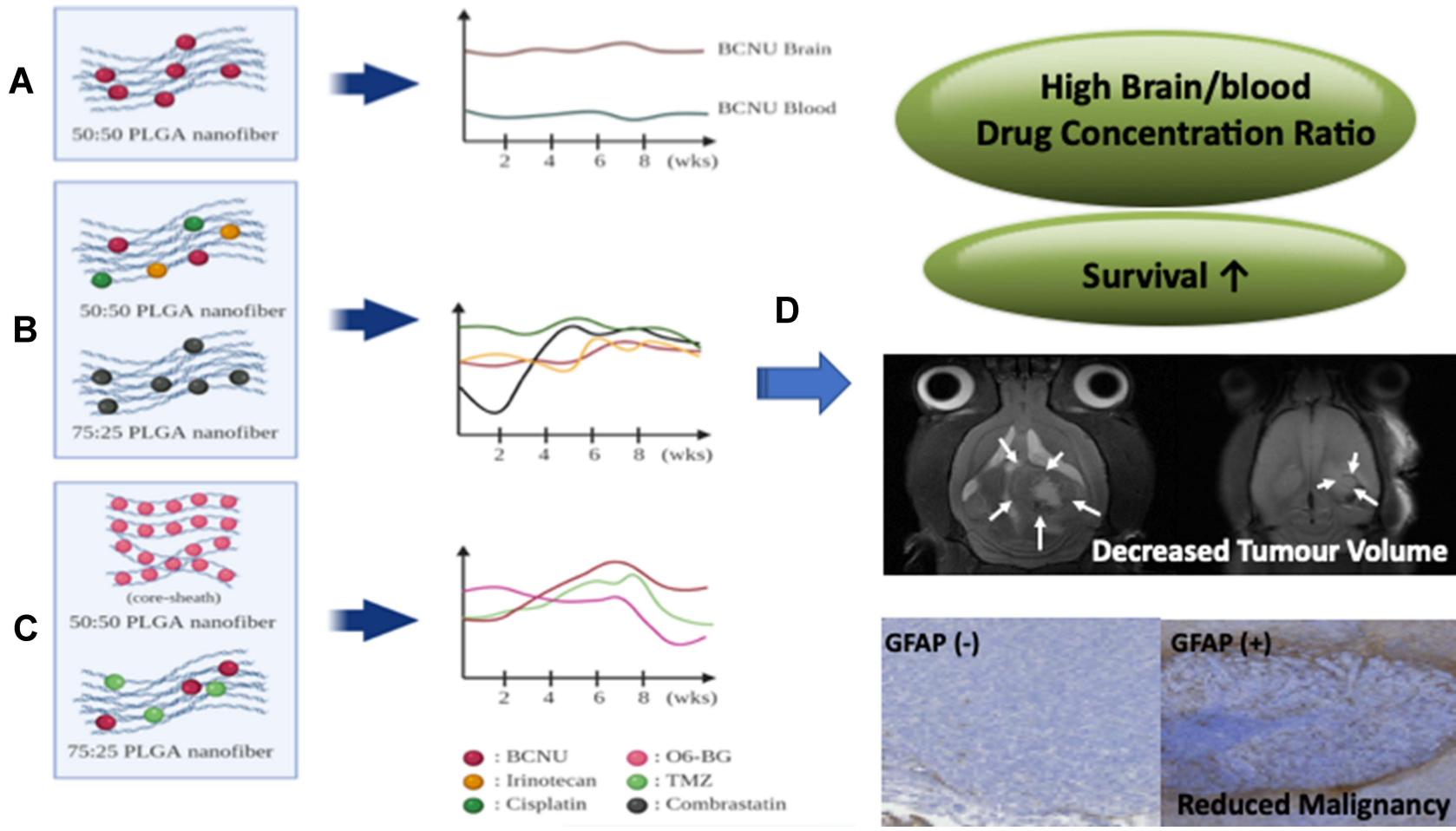

Figure 4 (A) Sustained release of a single chemotherapy agent (BCNU) from 50:50 PLGA nanofibrous membranes (NMs). (B) Sequential release of three chemotherapy agents (BCNU, irinotecan, and cisplatin) from 50:50 PLGA NMs followed by release of an antiangiogenetic agent (combrastatin) 75:25 PLGA NMs. (C) Sequential release of $\mathrm{O}^{6}$-BG from 50:50 PLGA NMs followed by release of two alkylating agents (BCNU and TMZ) from 75:25 PLGA NMs. (D) Contribution of NMs of different designs to antiglioma efficacy in an orthotopic animal model. 
anticancer-drug-loaded nanofibers can enhance therapeutic efficacy and minimize systemically toxic effects. These drug-loaded NMs require only short-term hospitalization, incur low costs from hospitalization and drugs, and improve the patient's quality of life.

\section{Strategies to Promote Drug Delivery Across the BBB}

Many novel strategies have been developed for effective drug delivery. Intravascular (generally intravenous) infusion is a common route for NP administration into the CNS. Injected NPs are rapidly cleared from the circulation, leading to a short retention time and consequently reduced BBB permeability. Studies have estimated that, at best, $<5 \%$ of initially administered NPs reach the CNS. ${ }^{113-115}$ The augmentation of NP surfaces with a variety of ligands can increase BBB penetration through transport- and receptor-mediated transcytosis or through increased particle retention in circulation. ${ }^{114}$ Targeting NPs through an externally applied magnetic field enhances NP retention in the CNS. Focused ultrasound (FUS) is a potential means for the targeted delivery of diagnostic or therapeutic particles to the brain without damaging surrounding normal tissues (Figure 3B). Table 2 presents the mechanism, advantages, and limitations of advanced local delivery and systemic delivery (with magnetic and FUS-assisted techniques).

\section{Surface-Decorated NPs}

Transferrin-containing gold NPs can reach the brain parenchyma through systemic administration in mice via a receptor-mediated transcytosis pathway. ${ }^{116}$ Studies have conjugated Angiopep-2 (ANG), a cell penetrating peptide, to NPs of iron and gold; the ability of the ANG-Fe-Au NP conjugate in restricting glioma growth through magnetic field-induced hyperthermia has then been assessed. ${ }^{99,114}$ Increasing NP retention in the circulation may facilitate brain uptake through ligands such as PEG, thus reducing NP opsonization and sequestering the reticuloendothelial system. ${ }^{117}$ Recently, zwitterionic materials were developed as alternatives to PEG to prolong the circulation of NPs without triggering an immune response. ${ }^{117}$ Chen et al. ${ }^{118}$ reported that PEG-coated PLGA nanoparticles had

Table 2 Comparison of Advanced Local Delivery with Systemic Delivery Methods for Treating MG

\begin{tabular}{|c|c|c|c|c|c|}
\hline & $\begin{array}{l}\text { Advanced Local } \\
\text { Delivery }\end{array}$ & Nanoparticle & $\begin{array}{l}\text { Surface- } \\
\text { Decorated } \\
\text { Nanoparticle }\end{array}$ & $\begin{array}{l}\text { Magnetic Assisted } \\
\text { Nanoparticle }\end{array}$ & Focused Ultrasound \\
\hline Mechanism & Bypassing BBB & Open BBB & $\begin{array}{l}\text { Open BBB } \\
\text { Increase retention }\end{array}$ & Increase retention of MNPs & $\begin{array}{l}\text { Increase permeability of } \\
\text { BBB }\end{array}$ \\
\hline Transport & $\begin{array}{l}\text { Direct release of } \\
\text { agents into tumor } \\
\text { site }\end{array}$ & Through BBB & Open BBB & $\begin{array}{l}\text { Tumor vascularity change } \rightarrow \\
\text { allow NP cross BBB }\end{array}$ & $\begin{array}{l}\text { Transient disruption of } \\
\text { BBB }\end{array}$ \\
\hline $\begin{array}{l}\text { Administration } \\
\text { route }\end{array}$ & $\begin{array}{l}\text { After tumor } \\
\text { resection } \\
\text { Intratumoral } \\
\text { injection* }\end{array}$ & $\begin{array}{l}\text { Intravascular } \\
\text { CED* }\end{array}$ & $\begin{array}{l}\text { Intravascular } \\
\text { CED* }\end{array}$ & $\begin{array}{l}\text { Intravascular } \\
\text { CED* }\end{array}$ & $\begin{array}{l}\text { Intravascular } \\
\text { CED* }\end{array}$ \\
\hline $\begin{array}{l}\text { Systemic } \\
\text { toxicity/ side } \\
\text { effect }\end{array}$ & Less & $\begin{array}{l}\text { As systemic } \\
\text { administration }\end{array}$ & $\begin{array}{l}\text { As systemic } \\
\text { administration }\end{array}$ & As systemic administration & As systemic administration \\
\hline Efficacy & 100 & $0.5-4.3 \%$ & $\begin{array}{l}0.8-21.2 \%(1.91- \\
4.93 \text { fold higher than } \\
N P)\end{array}$ & 3.6-12 fold higher than NP & $\begin{array}{l}2-10 \text { fold retention than } \\
\text { NP }\end{array}$ \\
\hline Limitation & $\begin{array}{l}\text { Short diffuse } \\
\text { distance }\end{array}$ & $\begin{array}{l}\text { Small size (15- } \\
20 \mathrm{~nm}) \text { is } \\
\text { preferred }\end{array}$ & $\begin{array}{l}\text { Small size }(15-20 \\
\mathrm{nm}) \text { is preferred }\end{array}$ & $\begin{array}{l}\text { Large nanoparticles (>100 nm) } \\
\text { may be difficult to target } M G s\end{array}$ & $\begin{array}{l}\text { Need image guided Small } \\
\text { size }(15-20 \mathrm{~nm}) \text { is } \\
\text { preferred }\end{array}$ \\
\hline
\end{tabular}

Note: *Need minimal operation- burr hole.

Abbreviations: MNP, magnetic nanoparticles; CED, convection-enhanced delivery. 
a penetration of $8.2 \%-21.2 \%$, which was better than that of PLGA nanoparticles (4.3\%).

\section{Magnetic Assistance-Based Techniques}

The magnetic characteristics of magnetic nanoparticles (MNPs) distinguish them from typical NPs. A synergetic drug transport strategy was formulated in previous studies, and it offered an approximately 3.4-fold enhancement of the drug's half-life (from 18 to $62 \mathrm{~h}$ ) and significantly extended the median survival rate of animals that received a low dose of BCNU relative to animals that received a high dose of free BCNU (63 days for those that received $4.5 \mathrm{mg} / \mathrm{kg}$ $\mathrm{BCNU}$ delivered through the nanocarrier vs 50 days for those that received $13.5 \mathrm{mg}$ of free $\mathrm{BCNU}$ ). This strategy enhances the potential of magnetic targeting treatment in clinical implementations of cancer therapies. ${ }^{119,120}$ A transferrin receptor-binding peptide T7-modified PLGA MNP system was prepared through the co-encapsulation of combination of two drugs (paclitaxel and curcumin) in hydrophobic MNPs. This dual-targeting, codelivery-MNP system provides synergistic effects in the inhibition of tumor growth and serves as a potential strategy for both delivering drugs to the brain and improving antiglioma efficacy. ${ }^{121}$ Moreover, the distinct magnetic characteristics of MNPs can be leveraged to induce local hyperthermia through safely employing magnetic fields in thermotherapy and magnetically targeting malignant brain cancers. ${ }^{99,122,123}$ Imaging findings have indicated that MNPs contribute to a 3.6-12-fold increase in MNP accumulation in brain tumors. ${ }^{121,124-126}$

\section{FUS-Assisted Techniques}

The application of FUS sonication where microbubbles appear can temporarily disrupt the BBB and increase its permeability. FUS sonication is an early-stage, noninvasive therapy with the potential to reduce the cost of treatment and improve quality of life for patients with brain tumors. The oscillation and destruction of microbubbles and microstreaming and the characteristics of radioactive forces are the most crucial parameters for transiently rupturing vascular barriers to increase the tumor's vascular permeability. ${ }^{127}$ This noninvasive technique enables the extent of drug delivery to be adjusted through repeated treatment and through controlling the length of sonications and intervals between them. ${ }^{128}$ Furthermore, repeated pulsed high-intensity focused ultrasound (HIFU) can be used to selectively transport high doses of atherosclerotic plaque-specific peptide-1 (AP-1)-conjugated liposomes to brain tumors. Moreover, the integration of repeated pulsed HIFU with both AP-1 liposomal doxorubicin and untargeted liposomal doxorubicin has exhibited similar antitumor effects. ${ }^{128-130}$ Previous studies have demonstrated that transcranial FUS exposure significantly increases permeation into the BBB by $2-10$ times. ${ }^{131-133}$ Compared with 3- and 120-nm NPs, medium-sized (15 to $20 \mathrm{~nm}$ ) NPs had the highest delivery efficacy. ${ }^{133,134}$

FUS and magnetic targeting have been synergistically employed to increase BBB permeability and the retention of chemotherapeutic or other biotherapeutic agents. Liu et al used epirubicin-embedded MNPs to treat tumor-bearing animals. Epirubicin transport through the BBB and accumulation in brain tumors were significantly strengthened by combining FUS-assisted and magnetic assistance-based therapies to target epirubicin MNPs. ${ }^{135} \mathrm{Li}$ et al developed polysorbate 80 modified paclitaxel-loaded PLGA NPs and enhanced local delivery into the brain for glioma treatment using FUS, resulting in significantly stronger antiglioma efficacy and increased survival time in tumor-bearing mice. ${ }^{136}$

\section{Conclusion}

Biodegradable drug delivery carriers, especially nanoscale variants, can allow drugs to bypass the $\mathrm{BBB}$, thus increasing the local concentrations of drugs at targeted sites of action to effective levels and reducing systemic adverse effects. Many immunotherapies and gene therapies have also been formulated for multimodal MG treatment. However, macromolecules (eg, antigens and antibodies, genes, peptides, and nucleic acid) in these therapies cannot directly penetrate the BBB and are sensitive to physical (temperature) and chemical (eg, solvent and $\mathrm{pH}$ ) factors, making the choice of the delivery vector vital. By using multiple chemotherapy agents in combination with different tumoricidal mechanisms or by adopting gene therapy and immunotherapy in the form of monotherapy or combinatorial therapy through concurrently loaded biopharmaceutical agents onto polymeric carriers, we may be able to overcome chemoresistance and offer more effective treatments.

NPs possess tremendous potential as drug delivery systems. Surface decoration of NPs can increase retention time in circulation and promote their uptake, the application of an external magnetic field can increase MNP accumulation in the targeted site (the brain), and FUS helps NPs to cross the BBB. All these treatment strategies help drugs permeate the BBB, and they are particularly valuable for patients who are unable to withstand a major 
operation or whose lesions are deep-seated and challenging to remove safely. Moreover, the treatment of malignant brain tumors through local hyperthermia is possible through the use of MNPs with the aid of pulsed HIFU or an external magnetic field. These technologies can be used in monotherapy or combined therapy for more effective treatment. MNPs not only serve to enhance tumor contrast in MRI but also offer targeted drug delivery, controlled release, and the induction of hyperthermia.

\section{Acknowledgments}

This work was sponsored by the Ministry of Science and Technology, Taiwan (Contract No. 110-2622-E-182-005), and Chang Gung Memorial Hospital (Contract No. CRRPD2K0011 and CRRPD2K0021). This manuscript was edited by Wallace Academic Editing.

\section{Disclosure}

The authors declare no conflicts of interest.

\section{References}

1. Ahmed R, Oborski MJ, Hwang M, Lieberman FS, Mountz JM. Malignant gliomas: current perspectives in diagnosis, treatment, and early response assessment using advanced quantitative imaging methods. Cancer Manag Res. 2014;6:149-170. doi:10.2147/ CMAR.S54726

2. Wen PY, Kesari S. Malignant gliomas in adults. $N$ Engl J Med. 2008;359(5):492-507. doi:10.1056/NEJMra0708126

3. Wong ET, Hess KR, Gleason MJ, et al. Outcomes and prognostic factors in recurrent glioma patients enrolled onto Phase II clinical trials. $J$ Clin Oncol. 1999;17(8):2572-2578. doi:10.1200/ JCO.1999.17.8.2572

4. Aoki T, Hashimoto N, Matsutani M. Management of glioblastoma. Expert Opin Pharmacother. 2007;8 (18):3133-3146. doi:10.1517/14656566.8.18.3133

5. Gallia GL, Brem S, Brem H. Local treatment of malignant brain tumors using implantable chemotherapeutic polymers. J Natl Compr Canc Netw. 2005;3(5):721-728. doi:10.6004/jnccn.2005.0042

6. Hsu BH, Lee WH, Yang ST, Han CT, Tseng YY. Spinal metastasis of glioblastoma multiforme before gliosarcomatous transformation: a case report. BMC Neurol. 2020;20(1):178. doi:10.1186/ s12883-020-01768-3

7. Stupp R, Hegi ME, van den Bent MJ, et al. Changing paradigms-an update on the multidisciplinary management of malignant glioma. Oncologist. 2006;11(2):165-180. doi:10.1634/theoncologist.11-2-165

8. Debinski W. Drug cocktails for effective treatment of glioblastoma multiforme. Expert Rev Neurother. 2008;8(4):515-517. doi:10.1586/14737175.8.4.515

9. Wick W, Wick A, Weiler M, Weller M. Patterns of progression in malignant glioma following anti-VEGF therapy: perceptions and evidence. Curr Neurol Neurosci Rep. 2011;11(3):305-312. doi:10.1007/s11910-011-0184-0

10. Lopez KA, Tannenbaum AM, Assanah MC, et al. Convectionenhanced delivery of topotecan into a PDGF-driven model of glioblastoma prolongs survival and ablates both tumor-initiating cells and recruited glial progenitors. Cancer Res. 2011;71 (11):3963-3971. doi:10.1158/0008-5472.CAN-10-0906
11. Tosi G, Ruozi B, Belletti D. Nanomedicine: the future for advancing medicine and neuroscience. Nanomedicine (Lond). 2012;7 (8):1113-1116. doi:10.2217/nnm.12.90

12. Pardridge WM. Drug targeting to the brain. Pharm Res. 2007;24 (9):1733-1744. doi:10.1007/s11095-007-9324-2

13. Tosi G, Costantino L, Ruozi B, Forni F, Vandelli MA. Polymeric nanoparticles for the drug delivery to the central nervous system. Expert Opin Drug Deliv. 2008;5(2):155-174. doi:10.1517/ 17425247.5.2.155

14. Pardridge WM. Blood-brain barrier drug targeting: the future of brain drug development. Mol Interv. 2003;3(2):90-105, 151. doi:10.1124/mi.3.2.90

15. Mundargi RC, Babu VR, Rangaswamy V, Patel P, Aminabhavi TM. Nano/micro technologies for delivering macromolecular therapeutics using poly(D,L-lactide-co-glycolide) and its derivatives. J Control Release. 2008;125(3):193-209. doi:10.1016/j.jconrel.2007.09.013

16. Barbu E, Molnar E, Tsibouklis J, Gorecki DC. The potential for nanoparticle-based drug delivery to the brain: overcoming the blood-brain barrier. Expert Opin Drug Deliv. 2009;6 (6):553-565. doi:10.1517/17425240902939143

17. Olivier JC. Drug transport to brain with targeted nanoparticles. NeuroRx. 2005;2(1):108-119. doi:10.1602/neurorx.2.1.108

18. Quinn JA, Desjardins A, Weingart J, et al. Phase I trial of temozolomide plus O6-benzylguanine for patients with recurrent or progressive malignant glioma. J Clin Oncol. 2005;23 (28):7178-7187. doi:10.1200/JCO.2005.06.502

19. Chamberlain MC. Temozolomide: therapeutic limitations in the treatment of adult high-grade gliomas. Expert Rev Neurother. 2010;10(10):1537-1544. doi:10.1586/ern.10.32

20. Fleming AB, Saltzman WM. Pharmacokinetics of the carmustine implant. Clin Pharmacokinet. 2002;41(6):403-419. doi:10.2165/ 00003088-200241060-00002

21. Tamargo RJ, Myseros JS, Epstein JI, Yang MB, Chasin M, Brem H. Interstitial chemotherapy of the 9L gliosarcoma: controlled release polymers for drug delivery in the brain. Cancer Res. 1993;53(2):329-333.

22. Attenello FJ, Mukherjee D, Datoo G, et al. Use of gliadel (BCNU) wafer in the surgical treatment of malignant glioma: a 10-year institutional experience. Ann Surg Oncol. 2008;15 (10):2887-2893. doi:10.1245/s10434-008-0048-2

23. Dietrich J. Chemotherapy associated central nervous system damage. Adv Exp Med Biol. 2010;678:77-85.

24. Westphal M, Hilt DC, Bortey E, et al. A Phase 3 trial of local chemotherapy with biodegradable carmustine (BCNU) wafers (Gliadel wafers) in patients with primary malignant glioma. Neuro Oncol. 2003;5(2):79-88. doi:10.1093/neuonc/5.2.79

25. Brem H, Piantadosi S, Burger PC, et al. Placebo-controlled trial of safety and efficacy of intraoperative controlled delivery by biodegradable polymers of chemotherapy for recurrent gliomas. The polymer-brain tumor treatment group. Lancet. 1995;345 (8956):1008-1012. doi:10.1016/S0140-6736(95)90755-6

26. Hart MG, Grant R, Garside R, Rogers G, Somerville M, Stein K. Chemotherapy wafers for high grade glioma. Cochrane Database Syst Rev. 2011;(3):CD007294. doi:10.1002/14651858.CD007294. pub2

27. Tseng YY, Kau YC, Liu SJ. Advanced interstitial chemotherapy for treating malignant glioma. Expert Opin Drug Deliv. 2016;13 (11):1533-1544. doi:10.1080/17425247.2016.1193153

28. Yen SY, Chen SR, Hsieh J, et al. Biodegradable interstitial release polymer loading a novel small molecule targeting Axl receptor tyrosine kinase and reducing brain tumour migration and invasion. Oncogene. 2016;35(17):2156-2165. doi:10.1038/onc.2015.277

29. Spicer CD, Pashuck ET, Stevens MM. Achieving controlled biomolecule-biomaterial conjugation. Chem Rev. 2018;118 (16):7702-7743. doi:10.1021/acs.chemrev.8b00253 
30. Tseng YY, Liu SJ. Nanofibers used for the delivery of analgesics. Nanomedicine (Lond). 2015;10(11):1785-1800. doi:10.2217/ nnm. 15.23

31. Tseng YY, Liao JY, Chen WA, Kao YC, Liu SJ. Biodegradable poly([D,L]-lactide-co-glycolide) nanofibers for the sustainable delivery of lidocaine into the epidural space after laminectomy. Nanomedicine (Lond). 2014;9(1):77-87. doi:10.2217/nnm.13.42

32. Schiapparelli P, Zhang P, Lara-Velazquez M, et al. Self-assembling and self-formulating prodrug hydrogelator extends survival in a glioblastoma resection and recurrence model. $J$ Control Release. 2020;319:311-321. doi:10.1016/j.jconrel.2020.01.003

33. Tseng YY, Yang TC, Chen SM, Yang ST, Tang YL, Liu SJ. Injectable SN-38-embedded polymeric microparticles promote antitumor efficacy against malignant glioma in an animal model. Pharmaceutics. 2020;12(5):479. doi:10.3390/pharmaceutics12 050479

34. Tseng YY, Kao CW, Liu KS, Tang YL, Liu YW, Liu SJ. Treating intracranial abscesses in rats with stereotactic injection of biodegradable vancomycin-embedded microparticles. Pharmaceutics. 2020;12(2):91. doi:10.3390/pharmaceutics 12020091

35. Liu SJ, Yang ST, Chen SM, et al. Novel multi-drugs incorporating hybrid-structured nanofibers enhance alkylating agent activity in malignant gliomas. Ther Adv Med Oncol. 2019;11:17588359 19875555. doi:10.1177/1758835919875555

36. Liu SJ, Yang TC, Yang ST, Chen YC, Tseng YY. Biodegradable hybrid-structured nanofibrous membrane supported chemoprotective gene therapy enhances chemotherapy tolerance and efficacy in malignant glioma rats. Artif Cells Nanomed Biotechnol. 2018;46(sup2):515-526. doi:10.1080/21691401.2018.1460374

37. Blumenthal DT, Rankin C, Stelzer KJ, et al. A Phase III study of radiation therapy (RT) and $\mathrm{O}(6)$-benzylguanine $+\mathrm{BCNU}$ versus $\mathrm{RT}$ and $\mathrm{BCNU}$ alone and methylation status in newly diagnosed glioblastoma and gliosarcoma: Southwest Oncology Group (SWOG) study S0001. Int J Clin Oncol. 2015;20(4):650-658. doi:10.1007/s10147-014-0769-0

38. Quinn JA, Jiang SX, Reardon DA, et al. Phase II trial of temozolomide plus o6-benzylguanine in adults with recurrent, temozolomide-resistant malignant glioma. J Clin Oncol. 2009;27 (8):1262-1267. doi:10.1200/JCO.2008.18.8417

39. Tseng YY, Liao JY, Chen WA, Kao YC, Liu SJ. Sustainable release of carmustine from biodegradable poly[((D,L))-lactideco-glycolide] nanofibrous membranes in the cerebral cavity: in vitro and in vivo studies. Expert Opin Drug Deliv. 2013;10 (7):879-888. doi:10.1517/17425247.2013.758102

40. Levin VA, Edwards MS, Wright DC, et al. Modified procarbazine, CCNU, and vincristine (PCV 3) combination chemotherapy in the treatment of malignant brain tumors. Cancer Treat Rep. 1980;64(2-3):237-244.

41. Kappelle AC, Postma TJ, Taphoorn MJ, et al. PCV chemotherapy for recurrent glioblastoma multiforme. Neurology. 2001;56 (1):118-120. doi:10.1212/WNL.56.1.118

42. Tseng YY, Wang YC, Su CH, et al. Concurrent delivery of carmustine, irinotecan, and cisplatin to the cerebral cavity using biodegradable nanofibers: in vitro and in vivo studies. Colloids Surf $B$ Biointerfaces. 2015;134:254-261. doi:10.1016/j. colsurfb.2015.06.055

43. Tseng YY, Huang YC, Yang TC, et al. Concurrent chemotherapy of malignant glioma in rats by using multidrug-loaded biodegradable nanofibrous membranes. Sci Rep. 2016;6(1):30630 doi:10.1038/srep30630

44. Smith SJ, Tyler BM, Gould T, et al. Overall survival in malignant glioma is significantly prolonged by neurosurgical delivery of etoposide and temozolomide from a thermo-responsive biodegradable paste. Clin Cancer Res. 2019;25(16):5094-5106. doi:10.1158/1078-0432.CCR-18-3850
45. Yang J, Shi Z, Liu R, Wu Y, Zhang X. Combined-therapeutic strategies synergistically potentiate glioblastoma multiforme treatment via nanotechnology. Theranostics. 2020;10 (7):3223-3239. doi:10.7150/thno.40298

46. Tseng YY, Su CH, Yang ST, et al. Advanced interstitial chemotherapy combined with targeted treatment of malignant glioma in rats by using drug-loaded nanofibrous membranes. Oncotarget. 2016;7(37):59902-59916. doi:10.18632/oncotarget.10989

47. Galstyan A, Markman JL, Shatalova ES, et al. Blood-brain barrier permeable nano immunoconjugates induce local immune responses for glioma therapy. Nat Commun. 2019;10(1):3850. doi:10.1038/s41467-019-11719-3

48. Kozielski KL, Ruiz-Valls A, Tzeng SY, et al. Cancer-selective nanoparticles for combinatorial siRNA delivery to primary human GBM in vitro and in vivo. Biomaterials. 2019;209:79-87. doi:10.1016/j.biomaterials.2019.04.020

49. Jain KK. Role of nanobiotechnology in the personalized management of glioblastoma multiforme. Nanomedicine (Lond). 2011;6 (3):411-414. doi: $10.2217 / \mathrm{nnm} .11 .12$

50. Sneed PK, Gutin PH, Larson DA, et al. Patterns of recurrence of glioblastoma multiforme after external irradiation followed by implant boost. Int $J$ Radiat Oncol Biol Phys. 1994;29 (4):719-727. doi:10.1016/0360-3016(94)90559-2

51. Halperin EC, Burger PC, Bullard DE. The fallacy of the localized supratentorial malignant glioma. Int J Radiat Oncol Biol Phys. 1988;15(2):505-509. doi:10.1016/S0360-3016(98)90036-0

52. Raza SM, Pradilla G, Legnani FG, et al. Local delivery of antineoplastic agents by controlled-release polymers for the treatment of malignant brain tumours. Expert Opin Biol Ther. 2005;5 (4):477-494. doi:10.1517/14712598.5.4.477

53. Wu Q, Yang Z, Nie Y, Shi Y, Fan D. Multi-drug resistance in cancer chemotherapeutics: mechanisms and lab approaches. Cancer Lett. 2014;347(2):159-166. doi:10.1016/j.canlet.2014.03.013

54. Vadlapatla RK, Vadlapudi AD, Pal D, Mitra AK. Mechanisms of drug resistance in cancer chemotherapy: coordinated role and regulation of efflux transporters and metabolizing enzymes. Curr Pharm Des. 2013;19(40):7126-7140. doi:10.2174/ 13816128113199990493

55. Mazurek M, Litak J, Kamieniak P, et al. Metformin as potential therapy for high-grade glioma. Cancers (Basel). 2020;12(1).

56. Vasan N, Baselga J, Hyman DM. A view on drug resistance in cancer. Nature. 2019;575(7782):299-309. doi:10.1038/s41586-019-1730-1

57. Tomita T. Interstitial chemotherapy for brain tumors: review. J Neurooncol. 1991;10(1):57-74. doi:10.1007/BF00151247

58. Xu X, Chen X, Xu X, et al. BCNU-loaded PEG-PLLA ultrafine fibers and their in vitro antitumor activity against Glioma C6 cells. J Control Release. 2006;114(3):307-316.

59. Xie J, Macewan MR, Willerth SM, et al. Conductive core-sheath nanofibers and their potential application in neural tissue engineering. Adv Funct Mater. 2009;19(14):2312-2318. doi:10.1002/adfm.200801904

60. Yu M, Yao Q, Zhang Y, et al. Core/shell PLGA microspheres with controllable in vivo release profile via rational core phase design. Artif Cells Nanomed Biotechnol. 2018;1-10.

61. Zhao M, Danhier F, Bastiancich C, et al. Post-resection treatment of glioblastoma with an injectable nanomedicine-loaded photopolymerizable hydrogel induces long-term survival. Int J Pharm. 2018;548(1):522-529. doi:10.1016/j.ijpharm.2018.07.033

62. Lee JS, An TK, Chae GS, et al. Evaluation of in vitro and in vivo antitumor activity of BCNU-loaded PLGA wafer against 9L gliosarcoma. Eur J Pharm Biopharm. 2005;59(1):169-175. doi:10.1016/j.ejpb.2004.06.006

63. Seong H, An TK, Khang G, Choi SU, Lee CO, Lee HB. BCNUloaded poly(D, L-lactide-co-glycolide) wafer and antitumor activity against XF-498 human CNS tumor cells in vitro. Int J Pharm. 2003;251(1-2):1-12. doi:10.1016/S0378-5173(02)00543-4 
64. Sipos EP, Tyler B, Piantadosi S, Burger PC, Brem H. Optimizing interstitial delivery of $\mathrm{BCNU}$ from controlled release polymers for the treatment of brain tumors. Cancer Chemother Pharmacol. 1997;39(5):383-389. doi:10.1007/s002800050588

65. Tyler B, Wadsworth S, Recinos V, et al. Local delivery of rapamycin: a toxicity and efficacy study in an experimental malignant glioma model in rats. Neuro Oncol. 2011;13(7):700-709. doi:10.1093/neuonc/nor050

66. Weingart JD, Thompson RC, Tyler B, Colvin OM, Brem H. Local delivery of the topoisomerase I inhibitor camptothecin sodium prolongs survival in the rat intracranial 9L gliosarcoma model. Int J Cancer. 1995;62(5):605-609. doi:10.1002/ijc.2910620519

67. Palakurthi S. Challenges in SN38 drug delivery: current success and future directions. Expert Opin Drug Deliv. 2015;12 (12):1911-1921. doi:10.1517/17425247.2015.1070142

68. Zhang R, Saito R, Mano Y, et al. Convection-enhanced delivery of SN-38-loaded polymeric micelles (NK012) enables consistent distribution of SN-38 and is effective against rodent intracranial brain tumor models. Drug Deliv. 2016;23(8):2780-2786. doi:10.3109/10717544.2015.1081994

69. Manaspon C, Nasongkla N, Chaimongkolnukul K, et al. Injectable SN-38-loaded polymeric depots for cancer chemotherapy of glioblastoma multiforme. Pharm Res. 2016;33 (12):2891-2903. doi:10.1007/s11095-016-2011-4

70. Zhu X, Ni S, Xia T, et al. Anti-neoplastic cytotoxicity of SN-38loaded PCL/gelatin electrospun composite nanofiber scaffolds against human glioblastoma cells in vitro. J Pharm Sci. 2015;104(12):4345-4354. doi:10.1002/jps.24684

71. Affronti ML, Heery CR, Herndon JE 2nd, et al. Overall survival of newly diagnosed glioblastoma patients receiving carmustine wafers followed by radiation and concurrent temozolomide plus rotational multiagent chemotherapy. Cancer. 2009;115 (15):3501-3511. doi:10.1002/cncr.24398

72. Afsharzadeh M, Hashemi M, Mokhtarzadeh A, Abnous K, Ramezani M. Recent advances in co-delivery systems based on polymeric nanoparticle for cancer treatment. Artif Cells Nanomed Biotechnol. 2017;1-16.

73. Afsharzadeh M, Hashemi M, Mokhtarzadeh A, Abnous K, Ramezani M. Recent advances in co-delivery systems based on polymeric nanoparticle for cancer treatment. Artif Cells Nanomed Biotechnol. 2018;46 (6):1095-1110. doi:10.1080/21691401.2017.1376675

74. Friedman HS, Keir ST, Houghton PJ. The emerging role of irinotecan (CPT-11) in the treatment of malignant glioma in brain tumors. Cancer. 2003;97(9 Suppl):2359-2362. doi: $10.1002 /$ cncr. 11305

75. Bijnsdorp IV, Giovannetti E, Peters GJ. Analysis of drug interactions. Methods Mol Biol. 2011;731:421-434.

76. Haar CP, Hebbar P, Wallace GCT, et al. Drug resistance in glioblastoma: a mini review. Neurochem Res. 2012;37 (6):1192-1200. doi:10.1007/s11064-011-0701-1

77. Hanahan D, Bergers G, Bergsland E. Less is more, regularly: metronomic dosing of cytotoxic drugs can target tumor angiogenesis in mice. J Clin Invest. 2000;105(8):1045-1047. doi:10.1172/ JC19872

78. Wedge SR, Porteous JK, Newlands ES. Effect of single and multiple administration of an O6-benzylguanine/temozolomide combination: an evaluation in a human melanoma xenograft model. Cancer Chemother Pharmacol. 1997;40(3):266-272. doi: $10.1007 / \mathrm{s} 002800050657$

79. Chen X, Zhang M, Gan H, et al. A novel enhancer regulates MGMT expression and promotes temozolomide resistance in glioblastoma. Nat Commun. 2018;9(1):2949. doi:10.1038/ s41467-018-05373-4

80. Reijneveld JC, Voest EE, Taphoorn MJB. Angiogenesis in malignant primary and metastatic brain tumors. J Neurol. 2000;247 (8):597-608. doi:10.1007/s004150070128
81. Das S, Marsden PA. Angiogenesis in glioblastoma. $N$ Engl J Med. 2013;369(16):1561-1563. doi:10.1056/NEJMcibr1309402

82. Ahir BK, Engelhard HH, Lakka SS. Tumor development and angiogenesis in adult brain tumor: glioblastoma. Mol Neurobiol. 2020;57(5):2461-2478. doi:10.1007/s12035-020-01892-8

83. Ahluwalia MS, Gladson CL. Progress on antiangiogenic therapy for patients with malignant glioma. J Oncol. 2010;2010:689018. doi: $10.1155 / 2010 / 689018$

84. Siemann DW, Mercer E, Lepler S, Rojiani AM. Vascular targeting agents enhance chemotherapeutic agent activities in solid tumor therapy. Int J Cancer. 2002;99(1):1-6. doi:10.1002/ijc.10316

85. Adair JE, Johnston SK, Mrugala MM, et al. Gene therapy enhances chemotherapy tolerance and efficacy in glioblastoma patients. J Clin Invest. 2014;124(9):4082-4092. doi:10.1172/ JCI76739

86. Tseng YY, Yang TC, Wang YC, et al. Targeted concurrent and sequential delivery of chemotherapeutic and antiangiogenic agents to the brain by using drug-loaded nanofibrous membranes. Int J Nanomedicine. 2017;12:1265-1276.

87. Wurth R, Pattarozzi A, Gatti M, et al. Metformin selectively affects human glioblastoma tumor-initiating cell viability: a role for metformin-induced inhibition of Akt. Cell Cycle. 2013;12 (1):145-156. doi:10.4161/cc.23050

88. Lee JE, Lim JH, Hong YK, Yang SH. High-dose metformin plus temozolomide shows increased anti-tumor effects in glioblastoma in vitro and in vivo compared with monotherapy. Cancer Res Treat. 2018;50(4):1331-1342. doi:10.4143/crt.2017.466

89. Adeberg S, Bernhardt D, Harrabi SB, et al. Metformin enhanced in vitro radiosensitivity associates with $\mathrm{G} 2 / \mathrm{M}$ cell cycle arrest and elevated adenosine-5'-monophosphate-activated protein kinase levels in glioblastoma. Radiol Oncol. 2017;51(4):431-437. doi:10.1515/raon-2017-0042

90. Taghizadehghalehjoughi A, Hacimuftuoglu A, Cetin M, et al. Effect of metformin/irinotecan-loaded poly-lactic-co-glycolic acid nanoparticles on glioblastoma: in vitro and in vivo studies. Nanomedicine (Lond). 2018;13(13):1595-1606. doi:10.2217/ nnm-2017-0386

91. Orunoglu M, Kaffashi A, Pehlivan SB, et al. Effects of curcumin-loaded PLGA nanoparticles on the RG2 rat glioma model. Mater Sci Eng C Mater Biol Appl. 2017;78:32-38. doi:10.1016/j.msec.2017.03.292

92. Brat DJ, Mapstone TB. Malignant glioma physiology: cellular response to hypoxia and its role in tumor progression. Ann Intern Med. 2003;138(8):659-668. doi:10.7326/0003-4819-1388-200304150-00014

93. Sneed PK, Stauffer PR, Gutin PH, et al. Interstitial irradiation and hyperthermia for the treatment of recurrent malignant brain tumors. Neurosurgery. 1991;28(2):206-215. doi:10.1227/ 00006123-199102000-00006

94. Gillette EL. Clinical use of thermal enhancement and therapeutic gain for hyperthermia combined with radiation or drugs. Cancer Res. 1984;44(10 Suppl):4836s-4841s.

95. Holste KG, Orringer DA. Laser interstitial thermal therapy. Neurooncol Adv. 2020;2(1):vdz035. doi:10.1093/noajn1/vdz035

96. Pinel S, Thomas N, Boura C, Barberi-Heyob M. Approaches to physical stimulation of metallic nanoparticles for glioblastoma treatment. Adv Drug Deliv Rev. 2019;138:344-357. doi:10.1016/ j.addr.2018.10.013

97. Shirvalilou S, Khoei S, Esfahani AJ, et al. Magnetic hyperthermia as an adjuvant cancer therapy in combination with radiotherapy versus radiotherapy alone for recurrent/progressive glioblastoma: a systematic review. $J$ Neurooncol. 2021;152(3):419-428. doi:10.1007/s11060-021-03729-3

98. Salehi A, Kamath AA, Leuthardt EC, Kim AH. Management of intracranial metastatic disease with laser interstitial thermal therapy. Front Oncol. 2018;8:499. doi:10.3389/fonc.2018.00499 
99. Hsu SPC, Dhawan U, Tseng YY, et al. Glioma-sensitive delivery of angiopep-2 conjugated iron gold alloy nanoparticles ensuring simultaneous tumor imaging and hyperthermia mediated cancer theranostics. Appl Mater Today. 2020;18:100510. doi:10.1016/j. apmt.2019.100510

100. Kamath AA, Friedman DD, Akbari SHA, et al. Glioblastoma treated with magnetic resonance imaging-guided laser interstitial thermal therapy: safety, efficacy, and outcomes. Neurosurgery. 2019;84(4):836-843. doi:10.1093/neuros/nyy375

101. Li S, Deng Q, Li X, et al. Bis-diketopyrrolopyrrole conjugated polymer nanoparticles as photothermic nanoagonist for specific and synergistic glioblastoma therapy. Biomaterials. 2019;216:119252. doi:10.1016/j.biomaterials.2019.119252

102. Ohtake M, Umemura M, Sato I, et al. Hyperthermia and chemotherapy using $\mathrm{Fe}$ (Salen) nanoparticles might impact glioblastoma treatment. Sci Rep. 2017;7:42783. doi:10.1038/srep42783

103. Borasi G, Nahum A, Paulides MM, et al. Fast and high temperature hyperthermia coupled with radiotherapy as a possible new treatment for glioblastoma. J Ther Ultrasound. 2016;4(1):32. doi:10.1186/s40349-016-0078-3

104. Avecillas-Chasin JM, Atik A, Mohammadi AM, Barnett GH. Laser thermal therapy in the management of high-grade gliomas. Int $J$ Hyperthermia. 2020;37(2):44-52. doi:10.1080/ 02656736.2020 .1767807

105. Thomas JG, Rao G, Kew Y, Prabhu SS. Laser interstitial thermal therapy for newly diagnosed and recurrent glioblastoma. Neurosurg Focus. 2016;41(4):E12. doi:10.3171/2016.7. FOCUS16234

106. Lennernas H, Regardh CG. Evidence for an interaction between the beta-blocker pafenolol and bile salts in the intestinal lumen of the rat leading to dose-dependent oral absorption and double peaks in the plasma concentration-time profile. Pharm Res. 1993;10(6):879-883. doi:10.1023/A:1018965328626

107. Decuzzi P, Pasqualini R, Arap W, Ferrari M. Intravascular delivery of particulate systems: does geometry really matter? Pharm Res. 2009;26(1):235-243. doi:10.1007/s11095-008-9697-x

108. Hoshyar N, Gray S, Han H, Bao G. The effect of nanoparticle size on in vivo pharmacokinetics and cellular interaction. Nanomedicine (Lond). 2016;11(6):673-692. doi:10.2217/nnm.16.5

109. Liao WY, Li HJ, Chang MY, Tang AC, Hoffman AS, Hsieh PC. Comprehensive characterizations of nanoparticle biodistribution following systemic injection in mice. Nanoscale. 2013;5 (22):11079-11086. doi:10.1039/c3nr03954d

110. Ramachandran R, Junnuthula VR, Gowd GS, et al. Theranostic 3-dimensional nano brain-implant for prolonged and localized treatment of recurrent glioma. Sci Rep. 2017;7(1):43271. doi:10.1038/srep43271

111. Sun L, Joh DY, Al-Zaki A, et al. Theranostic application of mixed gold and superparamagnetic iron oxide nanoparticle micelles in glioblastoma multiforme. J Biomed Nanotechnol. 2016;12 (2):347-356. doi:10.1166/jbn.2016.2173

112. Yao J, Hsu CH, Li Z, et al. Magnetic resonance nano-theranostics for glioblastoma multiforme. Curr Pharm Des. 2015;21 (36):5256-5266. doi:10.2174/1381612821666150923103307

113. Sonvico F, Clementino A, Buttini F, et al. Surface-modified nanocarriers for nose-to-brain delivery: from bioadhesion to targeting. Pharmaceutics. 2018;10(1):34. doi:10.3390/ pharmaceutics 10010034

114. Cena V, Jativa P. Nanoparticle crossing of blood-brain barrier: a road to new therapeutic approaches to central nervous system diseases. Nanomedicine (Lond). 2018;13(13):1513-1516. doi:10.2217/nnm-2018-0139

115. Saucier-Sawyer JK, Deng Y, Seo YE, et al. Systemic delivery of blood-brain barrier-targeted polymeric nanoparticles enhances delivery to brain tissue. J Drug Target. 2015;23(7-8):736-749. doi:10.3109/1061186X.2015.1065833
116. Wiley DT, Webster P, Gale A, Davis ME. Transcytosis and brain uptake of transferrin-containing nanoparticles by tuning avidity to transferrin receptor. Proc Natl Acad Sci U S A. 2013;110 (21):8662-8667. doi:10.1073/pnas.1307152110

117. Ou H, Cheng T, Zhang Y, et al. Surface-adaptive zwitterionic nanoparticles for prolonged blood circulation time and enhanced cellular uptake in tumor cells. Acta Biomater. 2018;65:339-348. doi:10.1016/j.actbio.2017.10.034

118. Chen YC, Hsieh WY, Lee WF, Zeng DT. Effects of surface modification of PLGA-PEG-PLGA nanoparticles on loperamide delivery efficiency across the blood-brain barrier. $J$ Biomater Appl. 2013;27(7):909-922. doi:10.1177/0885328211429495

119. Yang HW, Hua MY, Liu HL, et al. Self-protecting core-shell magnetic nanoparticles for targeted, traceable, long half-life delivery of BCNU to gliomas. Biomaterials. 2011;32 (27):6523-6532. doi:10.1016/j.biomaterials.2011.05.047

120. Veiseh O, Gunn JW, Zhang M. Design and fabrication of magnetic nanoparticles for targeted drug delivery and imaging. Adv Drug Deliv Rev. 2010;62(3):284-304. doi:10.1016/j.addr.2009.11.002

121. Cui Y, Zhang M, Zeng F, Jin H, Xu Q, Huang Y. Dual-targeting magnetic PLGA nanoparticles for codelivery of paclitaxel and curcumin for brain tumor therapy. ACS Appl Mater Interfaces. 2016;8(47):32159-32169. doi:10.1021/acsami.6b10175

122. Jordan A, Scholz R, Maier-Hauff K, et al. The effect of thermotherapy using magnetic nanoparticles on rat malignant glioma. $J$ Neurooncol. 2006;78(1):7-14. doi:10.1007/s11060-005-9059-z

123. Wankhede M, Bouras A, Kaluzova M, Hadjipanayis CG. Magnetic nanoparticles: an emerging technology for malignant brain tumor imaging and therapy. Expert Rev Clin Pharmacol. 2012;5(2):173-186. doi:10.1586/ecp.12.1

124. Chertok B, Moffat BA, David AE, et al. Iron oxide nanoparticles as a drug delivery vehicle for MRI monitored magnetic targeting of brain tumors. Biomaterials. 2008;29(4):487-496. doi:10.1016/ j.biomaterials.2007.08.050

125. Zhang L, Yu F, Cole AJ, et al. Gum arabic-coated magnetic nanoparticles for potential application in simultaneous magnetic targeting and tumor imaging. AAPS J. 2009;11(4):693-699. doi:10.1208/s12248-009-9151-y

126. Chertok B, David AE, Huang Y, Yang VC. Glioma selectivity of magnetically targeted nanoparticles: a role of abnormal tumor hydrodynamics. J Control Release. 2007;122(3):315-323. doi:10.1016/j.jconrel.2007.05.030

127. Liu H-L, Hua M-Y, Chen P-Y, et al. Blood-brain barrier disruption with focused ultrasound enhances delivery of chemotherapeutic drugs for glioblastoma treatment. Radiology. 2010;255 (2):415-425. doi:10.1148/radiol.10090699

128. Yang FY, Lin YS, Kang KH, Chao TK. Reversible blood-brain barrier disruption by repeated transcranial focused ultrasound allows enhanced extravasation. J Control Release. 2011;150 (1):111-116. doi:10.1016/j.jconrel.2010.10.038

129. Yang FY, Teng MC, Lu M, et al. Treating glioblastoma multiforme with selective high-dose liposomal doxorubicin chemotherapy induced by repeated focused ultrasound. Int J Nanomedicine. 2012;7:965-974. doi:10.2147/IJN.S29229

130. Yang FY, Wang HE, Lin GL, et al. Micro-SPECT/CT-based pharmacokinetic analysis of $99 \mathrm{mTc}$-diethylenetriaminepentaacetic acid in rats with blood-brain barrier disruption induced by focused ultrasound. J Nucl Med. 2011;52(3):478-484. doi:10.2967/jnumed.110.083071

131. Brighi C, Reid L, White AL, et al. MR-guided focused ultrasound increases antibody delivery to nonenhancing high-grade glioma. Neurooncol Adv. 2020;2(1):vdaa030. doi:10.1093/noajnl/vdaa030

132. Etame AB, Diaz RJ, Smith CA, Mainprize TG, Hynynen K, Rutka JT. Focused ultrasound disruption of the blood-brain barrier: a new frontier for therapeutic delivery in molecular neurooncology. Neurosurg Focus. 2012;32(1):E3. doi:10.3171/ 2011.10.FOCUS11252 
133. Ohta S, Kikuchi E, Ishijima A, Azuma T, Sakuma I, Ito T. Investigating the optimum size of nanoparticles for their delivery into the brain assisted by focused ultrasound-induced blood-brain barrier opening. Sci Rep. 2020;10(1):18220. doi:10.1038/s41598020-75253-9

134. Houston ZH, Bunt J, Chen KS, et al. Understanding the uptake of nanomedicines at different stages of brain cancer using a modular nanocarrier platform and precision bispecific antibodies. ACS Cent Sci. 2020;6(5):727-738. doi:10.1021/acscentsci.9b01299

135. Liu HL, Hua MY, Yang HW, et al. Magnetic resonance monitoring of focused ultrasound/magnetic nanoparticle targeting delivery of therapeutic agents to the brain. Proc Natl Acad Sci U S A. 2010;107(34):15205-15210. doi:10.1073/pnas.1003388107

136. Li Y, Wu M, Zhang N, et al. Mechanisms of enhanced antiglioma efficacy of polysorbate 80-modified paclitaxel-loaded PLGA nanoparticles by focused ultrasound. J Cell Mol Med. 2018;22 (9):4171-4182. doi:10.1111/jcmm.13695

137. Hua MY, Liu HL, Yang HW, et al. The effectiveness of a magnetic nanoparticle-based delivery system for BCNU in the treatment of gliomas. Biomaterials. 2011;32(2):516-527. doi:10.1016/j.biomaterials.2010.09.065

138. Steiniger SC, Kreuter J, Khalansky AS, et al. Chemotherapy of glioblastoma in rats using doxorubicin-loaded nanoparticles. Int J Cancer. 2004;109(5):759-767. doi:10.1002/ijc.20048

139. Wohlfart S, Khalansky AS, Gelperina S, et al. Efficient chemotherapy of rat glioblastoma using doxorubicin-loaded PLGA nanoparticles with different stabilizers. PLoS One. 2011;6(5): e19121. doi:10.1371/journal.pone.0019121

140. Roullin VG, Deverre JR, Lemaire L, et al. Anti-cancer drug diffusion within living rat brain tissue: an experimental study using [3H](6)-5-fluorouracil-loaded PLGA microspheres. Eur J Pharm Biopharm. 2002;53(3):293-299. doi:10.1016/S09396411(02)00011-5

141. Menei P, Boisdron-Celle M, Croue A, Guy G, Benoit JP. Effect of stereotactic implantation of biodegradable 5-fluorouracil-loaded microspheres in healthy and C6 glioma-bearing rats. Neurosurgery. $\quad 1996 ; 39(1): 117-123$; discussion 123-114. doi:10.1097/00006123-199607000-00023
142. Dalbasti T, Oktar N, Cagli S, Ozdamar N. Local interstitial chemotherapy with sustained release bucladesine in de novo glioblastoma multiforme: a preliminary study. $J$ Neurooncol. 2002;56(2):167-174. doi:10.1023/A:1014583820223

143. Ward SM, Skinner M, Saha B, Emrick T. Polymer-temozolomide conjugates as therapeutics for treating glioblastoma. Mol Pharm. 2018;15(11):5263-5276. doi:10.1021/acs.molpharmaceut.8b 00766

144. Turek A, Stoklosa K, Borecka A, et al. Designing biodegradable wafers based on poly(L-lactide-co-glycolide) and poly(glycolide-co-epsilon-caprolactone) for the prolonged and local release of idarubicin for the therapy of glioblastoma multiforme. Pharm Res. 2020;37(5):90. doi:10.1007/s11095-020-02810-2

145. Nance E, Zhang C, Shih TY, Xu Q, Schuster BS, Hanes J. Brainpenetrating nanoparticles improve paclitaxel efficacy in malignant glioma following local administration. ACS Nano. 2014;8 (10):10655-10664. doi:10.1021/nn504210g

146. Lee J, Cho HR, Cha GD, et al. Flexible, sticky, and biodegradable wireless device for drug delivery to brain tumors. Nat Commun. 2019;10(1):5205. doi:10.1038/s41467-019-13198-y

147. Tzeng SY, Green JJ. Subtle changes to polymer structure and degradation mechanism enable highly effective nanoparticles for siRNA and DNA delivery to human brain cancer. Adv Healthc Mater. 2013;2(3):468-480. doi:10.1002/adhm.201200257

148. Bikhezar F, de Kruijff RM, van der Meer A, et al. Preclinical evaluation of binimetinib (MEK162) delivered via polymeric nanocarriers in combination with radiation and temozolomide in glioma. J Neurooncol. 2020;146(2):239-246. doi:10.1007/ s11060-019-03365-y

149. Van Woensel M, Mathivet T, Wauthoz N, et al. Sensitization of glioblastoma tumor micro-environment to chemo- and immunotherapy by galectin-1 intranasal knock-down strategy. Sci Rep. 2017;7(1):1217. doi:10.1038/s41598-017-01279-1

150. Van Woensel M, Wauthoz N, Rosiere R, et al. Development of siRNA-loaded chitosan nanoparticles targeting galectin-1 for the treatment of glioblastoma multiforme via intranasal administration. J Control Release. 2016;227:71-81. doi:10.1016/ j.jconrel.2016.02.032
International Journal of Nanomedicine

\section{Publish your work in this journal}

The International Journal of Nanomedicine is an international, peerreviewed journal focusing on the application of nanotechnology in diagnostics, therapeutics, and drug delivery systems throughout the biomedical field. This journal is indexed on PubMed Central, MedLine, CAS, SciSearch ${ }^{\mathbb{R}}$, Current Contents ${ }^{\mathbb{R}} /$ Clinical Medicine,

\section{Dovepress}

Journal Citation Reports/Science Edition, EMBase, Scopus and the Elsevier Bibliographic databases. The manuscript management system is completely online and includes a very quick and fair peer-review system, which is all easy to use. Visit http://www.dovepress.com/ testimonials.php to read real quotes from published authors. 